\title{
JUSTICIA CON INTIMIDACIÓN: EL CASO DE LAS FARC
}

Gonzalo Cataño*

$\mathrm{E}_{\mathrm{y}}^{\mathrm{n}}$ n este ensayo se hace una exposición de las normas de las FARC y de su administración de justicia. Para ello, organiza su sistema jurídico tal como aparece en los textos publicados bajo los títulos de “estatuto”, “reglamento”,"normas”, “programas”,"plataformas”y “manuales de convivencia”, en pocas palabras: su derecho positivo. Estos materiales conforman el marco que les ha servido para formalizar la autoridad en sus filas y normalizar la dominación en las comunidades bajo su influencia y señorío.

Las fuentes no se redujeron, sin embargo, a sus códigos. También se hizo un buen número de entrevistas exploratorias con desmovilizados, hombres y mujeres de diversas edades, y se revisó la escasa literatura secundaria sobre la administración de justicia en las FARC escrita por otros investigadores. Si por metodología se entiende la lógica empleada en una investigación - la reunión de los datos, su organización y clasificación, su utilidad para ilustrar conceptos y teorías a fin de derivar conclusiones relevantes-, los pasos seguidos fueron bastante ilustrativos ${ }^{1}$. Los documentos de las FARC muestran

* Doctor en Sociología Jurídica, profesor de la Universidad Externado de Colombia, Bogotá, Colombia, [anomia45@outlook.com]. Agradezco a Mauricio Pérez, Carlos Bernal Pulido, Édgar Solano y Juan Camilo Rodríguez por su atenta lectura y sus provechosos comentarios a la versión original. Fecha de recepción: 23-01-2017, fecha de modificación: 04-03-2017, fecha de aceptación: 27-04-2017. Sugerencia de citación: Cataño, G. "Justicia con intimidación: el caso de las FARc", Revista de Economía Institucional 19, 36, 2017, pp. 95-148. DOI: https://doi.org/10.18601/01245996.v19n36.05.

${ }^{1}$ Lógica es noción asustadiza. Aquí se la acoge en su sentido más llano: teoría de las formas del pensar (Rickert, 1961, 10). Otros agregarían: y de investigar (Dewey, 1950, cap. 1).

En ciencias sociales se tiende a confundir la metodología con las técnicas de investigación empleadas en la recolección de los datos (uso de archivos, encuestas, censos, muestreos, series estadísticas, entrevistas, observaciones en el terreno, etc.). 
lo deseado y las entrevistas lo sentido y realizado por los actores. En los diálogos con los guerrilleros se exploraron las experiencias con el régimen disciplinario, su dinámica interna y la distancia entre lo prescrito y lo obedecido. Cuando los miembros de un grupo social, cualquiera que sea su tamaño, aceptan un orden normativo, sienten que se hace justicia cuando las reprimendas, los castigos, siguen la letra y el espíritu de los estatutos. Aquí la justicia es experimentada como seguimiento y aplicación adecuada de las leyes previamente aceptadas.

Aunque el trabajo es de naturaleza descriptiva, no abandona los intentos analíticos que guíen los datos provenientes de diversas fuentes. Los hechos sin conceptos derivados de una teoría que les brinde una dirección pierden su valor explicativo. Para ello se recurrió al sociólogo alemán Max Weber, muy interesado en la racionalización del derecho en la cultura occidental. Se ha tomado prestado su persistente señalamiento de las tensiones entre el derecho racional y el irracional, entre las prácticas jurídicas formales y las materiales (sustantivas). Creemos que esta perspectiva nos permite observar las singularidades de las FARC como manifestaciones de procesos más generales de los sistemas jurídicos.

Se discuten, igualmente, los fundamentos teóricos que orientan y legitiman su acción. Los dirigentes de las FARC organizan su lucha alrededor de un objetivo: la revolución. En esta empresa se adhieren a una tradición de pensamiento desarrollada por los ideólogos de la Unión Soviética durante los años veinte y treinta del siglo xx: el marxismoleninismo. Lo paradójico es que a pesar del fracaso de este programa revolucionario en la Rusia de Stalin, insisten en él como doctrina de transformación y cambio. En la práctica resulta en un artificio que se traduce en engaño de comunidades campesinas que creen verse orientadas por una notable y eficaz corriente científico-filosófica que les abre el camino de una utopía de protección y amparo, de bienestar, fraternidad y concordia. Se lucha, con las armas en la mano, por el socialismo para entrar al comunismo, un mundo de plenitud donde correrán "los manantiales de la riqueza colectiva”. Este es el evangelio

Pero en realidad va mucho más allá. En sentido estricto, metodología -la lógica en plena actividad- apunta a los procedimientos de búsqueda del conocimiento. Las estrategias empleadas en la reunión y procesamiento de información son apenas uno de sus elementos. El otro, no menos importante y significativo, es la elaboración teórica y la unión de los datos con los conceptos que le sirven de instrumento para asir y explicar la generalidad o particularidad de una situación, es decir, las decisiones teóricas y empíricas que están detrás de la presentación ordenada de un proceso social. Como señaló Paul Lazarsfeld, el padre de la metodología en la ciencia de Comte, "El sociólogo estudia al hombre en sociedad, el metodólogo estudia al sociólogo en acción” $(1965,40)$. 
que difunden los miembros del Partido Comunista Clandestino, la fuerza ideológica de las FARC, en las comunidades bajo su influencia.

Finalmente, se ofrece una reflexión sobre el pluralismo jurídico (la existencia de varios sistemas jurídicos en una nación) y la justicia popular (la justicia del pueblo). Sin duda, el derecho estatal y el de los alzados en armas son derechos hostiles y ajenos, pero el de las FARC es seguido, en sus comarcas, por un grupo significativo de colombianos. Hay pluralismo aunque el Estado no reconozca las normas de los insurgentes, de la misma manera que no reconoce la administración de justicia practicada por el crimen organizado en regiones enteras de la geografía nacional. El derecho de las FARC es derecho impuesto, heterónomo, reglas impuestas, no fruto de la deliberación de las personas que supuestamente deben obedecerlo, aunque ideológicamente se lo presente como defensa de los intereses del "pueblo", categoría de múltiples significados que se discute en una de las secciones del ensayo. $\mathrm{El}$ articulado de los manuales de convivencia que rige el comportamiento de las aldeas fue diseñado por los ideólogos y estrategas de la Organización "para bien de las comunidades", sin participación y consulta de los moradores de caseríos y veredas.

Este ensayo es una incursión inicial en un tema descuidado que sin duda será objeto de un examen más detenido en el futuro. Los procesos de justicia transicional lo pondrán en el orden del día. $\mathrm{Si}$ en el juicio que mañana se haga a un guerrillero y en su interrogatorio manifieste que ya fue castigado por las FARC por el delito que se le imputa surge - de facto- una manifestación de pluralismo. Si los jueces admiten la postura, o si conmueve la conciencia del jurado, se advertirá la presencia de una justicia ayer rechazada por el Estado. No es necesario estar de acuerdo con lo afirmado en estas páginas para descubrir que es un tema de interés. A veces los errores en busca del esclarecimiento de un suceso son más útiles para el saber y la práctica social que una verdad carente de importancia.

El texto comienza con una ligera descripción de la noción de justicia del cadí de Max Weber y termina con una reflexión sobre los elementos irracionales de la justicia popular promovida por las FARC. La noción del sociólogo alemán sirve para introducir el clima de la justicia fariana y los elementos irracionales para su conclusión. El aspecto central es la justicia de intimidación de la Organización y el empleo de su derecho positivo -sus reglamentaciones- en el manejo de los contingentes armados y de las comunidades bajo su égida. Se pone especial cuidado en el contenido de las ordenanzas y se ofrecen algunos ejemplos de su aplicación. En general es justicia de amenaza, 
manuales de convivencia proyectados para el dominio despótico de los poblados. Para organizar la información reunida sobre el derecho formal e informal en las FARC, que en su apurado enunciado y ejemplificación puede quedar disperso en la mente del lector, se recurre a la tipología jurídica de Weber de los derechos racional-irracional y sus correlaciones con las prácticas formales y materiales. En medio de estos quehaceres no se olvidan las labores ideológicas y formativas del Partido Comunista Clandestino de la Organización y el drástico estatuto que regula las tareas de sus miembros.

\section{LA JUSTICIA DEL CADÍ}

En un pasaje de Economía y sociedad dedicado a la dominación burocrática y al derecho moderno en Occidente, Weber se detuvo en un tipo de justicia antigua que se regía por criterios amplios: la justicia del cadí (2014,1167-1171). El cadí era un juez que realizaba sus funciones judiciales de acuerdo con la ley islámica, la sharia, "el mejor camino a seguir”. Allí el derecho y la religión estaban estrechamente unidos.

De los cadíes se esperaba el máximo ejemplo de moral y buenas costumbres, así como un amplio conocimiento y comprensión del Corán. Se los consideraba infalibles. Debían dar muestras de ecuanimidad y firmeza en sus decisiones y jamás apartarse de la tradición. El nombramiento de los cadíes, cuya existencia data de los siglos VII y viII, con desarrollos particulares en Damasco y en la España musulmana, era una prerrogativa de los soberanos y a ellos debían obediencia, pero en el ejercicio de sus funciones podían entrar en contradicción con los jeques y emires, que les temían ${ }^{2}$. Pocas veces los sultanes se atrevían a quebrantar sus sentencias y a subvertir su autoridad. Su cargo revestía dignidad y tenían gran ascendencia entre la población, ya que eran los encargados de mantener el orden $\mathrm{y}$ atender los litigios cotidianos. Actuaban como notarios y jueces de paz, y se pronunciaban en materia de matrimonios, divorcios, partición de bienes, litigios de muebles e inmuebles y en querellas de testamentos y sucesiones. No actuaban solos. En sus mejores días los acompañaban dos o tres ulemas, doctores en la ley mahometana, que los aconsejaban en sus decisiones. Contaban así mismo con un ujier que citaba a las partes, un escribano que registraba las disputas y unos gendarmes, la fuerza pública de la administración de justicia, que hacían cumplir las decisiones. Un viajero español por la Argelia de mediados del siglo XIX describió sus procedimientos:

2 Ver Battuta (1981, 140), Álvarez y Suárez (1991, 168-169) y, sobre todo, el comprensivo texto tan antiguo como actual del padre José López Ortiz (1932). 
E1 tribunal del cadí se reúne ordinariamente en las mezquitas en un cuartucho algo estrecho y oscuro en el cual hay una habitación interior para los g'adul [amanuenses]. El cadí se sienta sobre la alfombra que hay tendida en el suelo, y recostado sobre el almohadón oye las quejas de los que solicitan algo de su autoridad. En el momento que se presenta uno demandando a otro, si no lo conduce consigo, cosa que sucede las más de las veces, recibe orden un tschausch [alguacil] para salir a buscarlo y llevarlo ante el juez. Entonces el demandante expone su queja, el demandado contesta y el juez dicta sentencia que se lleva a efecto en el acto, aunque sea la de recibir uno de los comparecientes algunas docenas de palos.

Hemos dicho que el cadí abre su tribunal en la mezquita. Efectivamente, esto ha de suceder una vez al día por lo menos, pues el muftí, jefe de la ley y de la religión, cuida mucho de que así se haga; pero ordinariamente donde se administra justicia de paz es en los cafés y barberías donde concurren los cadíes. Allí, a vista de todo el mundo, se celebran los juicios y se dan las decisiones; y como estas la mayor parte de las veces son interrumpidas por las conversaciones generales de aquel sitio suelen ser como propias de él.

Las penas que se imponen por estos tribunales son conformes a la legislación musulmana; y si bien algunas están modificadas ya por las ordenanzas francesas [Argelia era por aquellos días colonia francesa], siempre son severísimas, y en prueba de ello mencionaremos algunas. Los ladrones, aunque sean de pequeña cantidad, son condenados a perder la mano derecha, operación que se hace a poco de haber pronunciado la sentencia. El mercader que tiene los pesos y medidas falsos pierde su mercancía y sufre una gran multa. E1 homicidio se castiga con la muerte, y las heridas graves lo mismo, si se han ocasionado con alevosía. Y el adulterio y la bancarrota fraudulenta tienen iguales penas ${ }^{3}$.

Para Weber, la justicia del cadí - un caso particular que elevó a concepto general- era lo opuesto al ejercicio del derecho formal tal como se lo conoce en Occidente después de la codificación del derecho romano. El modelo más desarrollado de este último, el que más se acerca al tipo ideal, está representado por la legislación que alcanzó su máxima expresión en los códigos y constituciones escritas de nuestros días. El derecho islámico de los cadíes era, por el contrario, una probidad donde las exhortaciones de la moral se entrelazaban con los mandatos de la ley; un derecho que se nutre de creencias, tradiciones y definiciones de lo bueno y de lo malo derivadas de las enseñanzas del

${ }^{3}$ Malo de Molina (1852, 183-185). Las sesiones de la justicia guerrillera recuerdan los escenarios del ejercicio del cadí. Cuando se trata de un miembro del grupo armado los juicios se efectúan en las zonas cuartelarias. El acusado está desarmado bajo el cuidado de un guerrillero. Cuando se emite un veredicto letal es conducido por dos o tres compañeros a un lugar apartado y en lejanía se escucha la detonación de una pistola. Horas después regresan los ejecutores con sendas palas al hombro. Los juicios a los miembros de las comunidades bajo su influencia tienen lugar en los patios o cobertizos de una finca. Rara vez hay ejecución, lo corriente es la expulsión. A los sospechosos de actividades contraguerrilleras los visita un miliciano -la policía de las FARC- o un guerrillero de la zona y les comunica que deben abandonar la vereda en dos o tres días. Si no atienden el llamado desaparecen: "la gente deja de verlos" (datos tomados de entrevistas con desmovilizados realizadas por el autor en agosto y septiembre de 2016; en adelante, "entrevistas con desmovilizados"). 
Corán. Es una ética religiosa que anima la administración de justicia. Allí la tradición, y una idea de ecuanimidad, están sin duda presentes, pero dada su amplitud y la dificultad para establecer límites, de hecho intervienen consideraciones ajenas al ejercicio racional del derecho.

Es lo que sucede en otros escenarios donde príncipes, jueces y gobernantes perdonan y enjuician a su arbitrio siguiendo principios éticos de naturaleza social o económica, acciones que ahogan los intentos de salvaguardar el rigor jurídico formal. No se enjuicia allí a todos por igual. La clemencia surge o es negada según los intereses políticos. Se tiene en cuenta el estatus de las personas o las exigencias del momento para formular las sentencias. Se está en el terreno liso de las justicias especiales para responder a tensiones singulares. Y cuando en épocas lejanas surgían situaciones límite, donde los humanos no tenían control alguno de la situación, se optaba por la vía de los oráculos y la voz de Dios. Era el terreno de lo inesperado y, como los jueces debían dar respuesta a toda disputa que llegara a sus tribunales, lo irracional afincado en el más allá no se hacía esperar. Su ejemplo más acabado eran las costumbres de principios de la Edad Media con las ordalías, la práctica judicial para obtener la verdad de una acusación. Se fundaba en la creencia de que el resultado final de un duelo o de una prueba física anunciaba el juicio de las fuerzas sobrenatuales siempre más sabias y esclarecidas que la de los humanos para hacer justicia. Dos historiadores de los años oscuros del medioevo italiano registraron sus pasos:

Las ordalías se desarrollaban en presencia de un juez, ante el cual se encontraban el acusado y la parte agraviada. El rito, que tenía lugar en el atrio de la iglesia, requería una gran olla de agua hirviendo y era precedido de una misa cantada a cuyo término el oficiante pronunciaba esta frase: "Haz, Señor, que pueda retirar sana e ilesa su mano de esta olla quien en ella la meta siendo inocente". Después, dirigiéndose al caldero, añadía: “Te bendigo, oh agua que hierves al fuego, en el nombre del Padre, del Hijo y del Espíritu Santo". El imputado era invitado a meter la mano derecha en el recipiente. Si el miembro sufría quemaduras, la acusación estaba fundada; si salía ileso, era falsa (Montanelli y Gervaso, 2006, 198) ${ }^{4}$.

Esta no era una práctica exclusiva de la administración de justicia en la distante y brumosa Edad Media. Todavía en el siglo xıx y principios del xx se urdían remedos de juicios de Dios en los grupos más tradicionales de la sociedad gitana. Allí el juez, que a su vez era el jefe

${ }^{4}$ Ver también Brundage $(2001,385)$, la sobria monografía de King (1981, 41 y 144) y el clásico moderno del derecho medieval de Berman (1996, 67). Los duelos seguían pasos semejantes. Se desarrollaban a campo abierto y quien saliera ileso del combate era inocente. Al perdedor se le amputaba la mano derecha. Los que se sometían a los juicios de Dios, o a los duelos, no podían usar amuletos o llevar hierbas encantadas. Estos accesorios de magia y embrujo podían distorsionar los resultados de las disputas. 
de la comunidad, tenía derecho de vida y muerte, de excomunión y destierro personal y colectivo para castigar robos, adulterios, homicidios o incumplimiento en los pagos. Liderazgo y magistratura se confundían hasta hacerse roles difíciles de diferenciar, ya que de la calidad de líder se derivaba la capacidad de juzgar. En casos graves y de solución incierta, donde las pruebas flaqueaban, como aquellos derivados de valores asociados con el honor, el prestigio y la honra, el jefe podía ordenar un duelo, "a puñetazos en Inglaterra y a cuchillazos en Rumania, cuyo resultado valía como sentencia” (Bloch, 1962, $53)^{5}$. Los gitanos no recurrían a la justicia ordinaria. Día y noche se desplazaban en sus lentos y pesados carruajes-habitación afrontando periplos que podían tomar años antes de regresar a sus lugares de partida. Era una sociedad nómada que solucionaba sus altercados siguiendo usos cuyo origen se perdía en los confines de generaciones apenas recordadas.

En estas manifestaciones de lo "justo", donde la voluntad de Dios se manifiesta a través del sutil e impalpable lenguaje de la revelación, ya no se estaba en el mundo de lo controlado. Era justicia antojadiza; Salomón improvisando ecuanimidad y Sancho Panza usando su imaginación para solucionar querellas entre astutos moradores de la Ínsula Barataria (Weber, 2014, 889 y 1293).

De hecho, todo ordenamiento jurídico, escrito o no escrito, porta niveles formales e informales. Un juez puede pronunciar un veredicto siguiendo la letra de la ley (una infracción administrativa), o remitiéndose a su conciencia para derivar de ella lo que considera más equitativo (un litigio de herencias donde se favorece a los "débiles"). La primera, estrictamente formal, es una decisión técnica; la segunda, de carácter material, una resonancia de los valores aplaudidos por la sociedad e interiorizados por el juez. En este caso no se subvierte la norma escrita, pero se la observa con laxitud para lograr una aplicación "más justa”. El derecho material, típico del cadí, es aquel que atiende ante todo a la situación particular y a su resolución siguiendo creencias generalizadas que se juzgan válidas para salvar la armonía social. Un ejemplo extremo de estas manifestaciones, nada extrañas

${ }^{5}$ Aquí es donde la justicia del cadí se traduce en justicia "carismática", aquella que descansa en lo que está fuera de control, en el más allá. "Son derivados de la justicia carismática -escribió Weber- todas las clases de ordalías consideradas como medios de prueba" $(2014,1294)$. El caso descrito es, por lo demás, justicia carismática por partida doble: por quien la ejerce y por quien la sufre. La administra el líder - persona de cualidades únicas reconocidas por la comunidad-y la llevan a cabo dos individuos que se enfrentan "a puñetazos o a cuchillazos", a los que solo salva el milagro y la buena suerte. Juez y cosa juzgada portan los rasgos de lo extraordinario, de lo que apenas se puede prever. En este tribunal todo está lejos de la esfera de lo racional. 
en nuestros días, lo recordó Weber en sus conferencias bávaras cuando aludió al trabajo de los magistrados de Atenas. "El tribunal griego de los heliastas -señaló- dictaba justicia como el cadí; las partes trataban de influir sobre los jueces por procedimientos pasionales, lágrimas e imprecaciones al adversario" (Weber, 1956, 286). Los cronistas de la antigüedad recuerdan, además, que cuando la célebre hetaira Phryné compareció ante los heliastas por daños contra la moral, sorprendidos por su hermosura, la absolvieron.

En opinión de Weber esto es justicia irracional, administración de justicia con arreglo a valores. Justicia que no se orienta por normas fijas de un derecho formal racional, sino por postulados éticos, religiosos y políticos apropiados para responder a un caso especial. Decisiones "con consideración de la persona", como le gustaba decir, y como bien lo retrata el caso de la cortesana griega. La llamada "justicia revolucionaria"-los juicios temerarios de los grupos alzados en armas en pos de un mundo mejor- pertenece a este rango de problemas. Es una visión de lo justo que las FARC desean implantar en sus dominios. Weber, con ligeras adecuaciones, la habría considerado una extensión más de la justicia cadiazga, el giro usado por el padre López Ortiz al hablar del oficio del juez islámico $(1932,69)$.

\section{JUSTICIA CON INTIMIDACIÓN}

La justicia revolucionaria porta un hálito de improvisación asistida por el apuro y la inseguridad de la confrontación. Es justicia para defensa del grupo, protección de la pequeña sociedad que delinque o desea subvertir la sociedad mayor. Es supervivencia, acción rápida e impositiva en un entorno movedizo que no da espera; jurisdicción bélica para evitar la desaparición del grupo, mundo donde quien tiene el poder, las armas, define lo "justo" y le es permitido delinquir en nombre de todos. Los moradores saben que toda transgresión de las normas farianas anuncia el arribo de hombres y mujeres con fusil al hombro o de milicianos con abultadas muestras de una pistola en la cintura. Se lucha por el territorio, se lo afianza, se persuade a los indecisos o se los expulsa, y a los renuentes se los elimina. Cuando la situación se calma y desaparece el peligro, la dominación se estabiliza y la justicia revolucionaria tiende a ser rutinaria, a hacerse cotidiana y a emparentarse con algunos elementos del derecho estatal. Es justicia subjetiva en cuanto depende a menudo de las inclinaciones personales de quien la ejerce (los comandantes), y en cuanto obedece a los intereses de un grupo que intenta legitimar sus demandas particulares como beneficio general de los poblados en los que ejerce su autoridad. 
Cuando las FARC se estabilizan en una región, monopolizan la marcha de las tensiones civiles y penales y, tras ellas, la vida de la comunidad como un todo. Se hacen gobierno. Llenan vacíos afrontando ausencias y precariedades del Estado. Saben que quien participa en la resolución de conflictos cotidianos extiende su manto a otros ámbitos del organismo social. Los que vigilan los hurtos, los homicidios, las riñas hogareñas y la marcha de las "buenas costumbres" terminan incursionando en el comercio, la educación, la industria y la explotación agraria y minera. Crean impuestos, "vacunas", y una variedad de exacciones según las características de la zona. Como el cabecilla beduino, el habitante del desierto que imponía contribuciones a las personas, caravanas y grupos que pasaban por sus rocosos poblados (Weber, 2014, 184), las FARC -gracias a su séquito guerrero-instauran gravámenes a las actividades económicas que circulan por su territorio. La comunidad, y todo lo que se mueva en derredor, debe sufragar el modus vivendi y el modus operandi de los administradores del orden.

Unos ejemplos ilustran la dinámica de esta administración de justicia en las regiones cercadas por las $\mathrm{FARC}^{6}$. Un líder social del Caquetá apuntó:

Hay áreas del Caquetá en que las FARc controlan la explotación de fauna y flora, de hecho hay zonas del municipio de Solano donde están prohibidas la caza de animales silvestres y la deforestación. Lo mismo en el municipio de San Vicente, donde está prohibida la tala de grandes extensiones de árboles. Todo esto está controlado. En zonas de alta influencia guerrillera también intervienen en riñas. Las FARC no permiten que entre vecinos haya problemas $\mathrm{y}$, cuando los hay, tratan de solucionarlos.

Un habitante de Neiva, la capital del Huila, manifestó que hasta 2009, cuando merodeaba por la zona un comandante apodado "E1 Mocho", las FARC intervenían en conflictos matrimoniales, pago de deudas, acciones de "limpieza social" (expulsión o desaparición de ladrones, drogadictos, prostitutas, homosexuales, indigentes, etc.), pero desde que "E1 Mocho" fue asesinado las FARC abandonaron su intervención en estos asuntos?.

\footnotetext{
${ }^{6}$ No hay mucha información sobre la justicia de las FARC, pero las investigaciones realizadas por la Fundación Paz y Reconciliación con la ayuda de entidades internacionales y algunas oficinas del Estado of recen un examen preliminar. Aquí las publicaciones del sociólogo Ariel Ávila son las más relevantes y las de mayor carga analítica y prospectiva. Ver Ávila (2016), Ávila y Castro (2015) y Ávila y Valencia (2016, 31-112). Y no se debe olvidar el libro de Mario Aguilera (2014), rico en ejemplos y en enfoques analíticos.

${ }^{7}$ Las cosas, sin embargo, han cambiado en los últimos años. Las guerrillas se han hecho más laxas en asuntos sexuales. Los comandantes se hacen subir prostitutas a las montañas, permiten el consumo de marihuana para la "relajación" de los trabajadores de la coca y toleran el homosexualismo mientras sea discreto y lejos de todo "pavoneo", ostentación y alarde. Algunos grupos guerrilleros son
} 
Un natural de Florencia reveló, así mismo, que años atrás las FARC "no dejaban que en inspecciones y caseríos se estuviera bebiendo en días laborales. Castigaban a los borrachos poniéndolos a trabajar en obras que estaban haciendo o multándolos económicamente”. Y una mujer del municipio de Doncello señaló:

Mi marido se me fue con la vecina y me dejó sola con seis niños. Mírelos, uno detrás del otro. Yo me quedé con la finca, pero él se llevó las siete vacas y no tenía cómo darles de comer a mis hijos y menos podía, yo sola, trabajar la finca. Como aquí la Policía no resuelve nada fui donde Camilo de las Farc, y en cuatro días ya me tenía la platica. Si no fuera por las FARC no habría tenido nada que comer ${ }^{8}$.

Para completar el relato, Ariel Ávila, quien recogió el testimonio, agregó que las FARC ubicaron rápidamente al esposo de la señora en el cercano municipio San Vicente y allí el mencionado Camilo, tercero al mando de la columna móvil Teófilo Forero, envió a un miliciano en busca del esposo fugado. Una vez contactado se le informó que debía vender cuatro de las siete vacas para darle el dinero a su antigua esposa, a la que podía dejar siempre y cuando siguiera atendiendo el sustento de los hijos. Dos días después el convicto vendió el ganado. En la legislación colombiana, concluyó Ávila, "esto se llama un proceso de inasistencia alimentaria que tarda en promedio dos años en resolverse y que las FARC solucionaron en una semana”. Es un ejemplo de derecho de familia ejercido por un grupo armado fuera de la ley 9

El asunto descrito por Ávila parece haberse solucionado satisfactoriamente, pero nada sabemos de la suerte y las motivaciones de la otra parte, del marido que abandonó a su esposa para convivir con la vecina. Como en el caso de la querella de Cicerón contra Verres, donde solo se tiene la versión de Cicerón (el impugnador), aquí solo se conoce el reclamo de la mujer abandonada. ¿Cómo explicó el reo su conducta? ¿No debía atender obligaciones con la nueva compañera? Todo es silencio. Escuchamos las razones de la parte afectada, pero ninguna de la otra, situación que deja en el ánimo del observador

incluso dueños de tabernas, billares y cantinas-prostíbulos que usan para cumplir funciones de inteligencia en caseríos y cabeceras municipales (entrevistas con desmovilizados).

${ }^{8}$ Condensación de dos entrevistas efectuadas por Ávila (2016).

${ }^{9}$ En suma, la justicia estatal es ineficaz y onerosa. Los procesos se alargan, los abogados cuestan, los campesinos deben desplazarse a los centros urbanos y el papeleo en los tribunales exige habilidades de lectura y escritura. Es un recurso que solo pueden sufragar las clases medias y altas, lo cual lleva a que los grupos económicamente débiles experimenten "una denegación real de justicia” (Weber, $2014,860-861$ y 1168). Una vez entren en vigencia los procesos de justicia transicional, el Estado deberá llenar este vacío con prontitud y eficiencia llevando la justicia al campo, en vez de pretender que el campo la busque en la ciudad. 
desprevenido el sentimiento de que se hizo justicia y que todo terminó como debía ser.

Pero esta es una justicia suave, una forma de resolver conflictos cotidianos mediante la persuasión, el diálogo y la razón, aunque detrás está siempre el gesto armado. Las FARC también han recurrido a los temerarios juicios populares o consejos de seguridad, en los que el comandante reúne a la comunidad para expulsar personas o dirimir tensiones de algún monto y asegurar la estabilidad del grupo armado en el entorno que ha hecho suyo. En estos casos no hay presunción de inocencia ni derecho al debido proceso.

[Los juicios populares son] justicia déspota, rápida, “eficiente”, pero arrastra[n] todo tipo de arbitrariedades. Con solo comentarios, rumores e informaciones sin control y verificación de las versiones, se termina auspiciando una verdadera cacería de brujas. Es corriente que vecinos disgustados unos con otros, generalmente propietarios de pequeños predios con problemas de linderos, acudan a la guerrilla y acusen a su colindante de colaborar con la fuerza pública para promover su expulsión. Esto indujo a que muchos comandantes guerrilleros crearan enclaves autoritarios, lo cual terminó por perjudicar la legitimidad de las FARC en las regiones ${ }^{10}$.

Los juicios populares juzgan por aclamación, por una decisión masiva donde la oposición desaparece ante la ovación y palmoteo de la multitud reunida en un patio o en una escuela. La multitud, espoleada por integrantes de las FARC, se convierte en jurado y fuente de derecho y de justicia, sin posibilidad de reclamo. Es conformidad impuesta que estrangula la discrepancia; un expediente que parte de la creencia de que la mayoría -expresión formal de la democracia- tiene el derecho de hacerlo y decidirlo todo. El pueblo se erige en tirano y es usado para salvaguardar intereses particulares en nombre de la comunidad; un empleo de la democracia para constreñirla. Es la manifestación más palmaria de la tyrannie de la majorité, el concepto acuñado por Tocqueville para designar la opresión no ya de un déspota o de una clase dominante sino de la sociedad misma, que cubre sus imperiosas decisiones con el manto democrático de la cantidad. Ya lo había anunciado el poeta de todos los tiempos:

Es admirable

tener la fuerza de un gigante, pero es tiránico

servirse de ella como un gigante ${ }^{11}$.

${ }^{10}$ Condensación de las conclusiones de Ávila (2016).

11 Versos de Shakespeare en Medida por medida (acto II, escena 2, 109-111) recordados por el jurista e historiador británico James Bryce en su examen de la tiranía de la mayoría en el capítulo 84 de The American Commonwealth; ver Bryce (1966, 107). La fuente del concepto se encuentra en Alexis de Tocqueville (1989, vol. I, segunda parte, cap. viI). Por su lado, el amigo de Tocqueville, el inglés J. S. Mill, señaló que esta tiranía era uno de esos males contra los que siempre hay que mantenerse en guardia: "encadena el alma" y bajo el ropaje de democracia e igualdad 
Ante los desmanes de los juicios populares, que en realidad eran consejos de seguridad auspiciados por las FARC para salvaguardar su permanencia en las regiones, los comandantes optaron por ceder las labores de justicia a las mismas comunidades. Para ello auspiciaron las Juntas de Acción Comunal (JAC) y difundieron un Manual de convivencia destinado a vigilar el comportamiento de las localidades ${ }^{12}$. El tema central y reiterativo de su articulado, "velar por la seguridad y bienestar de todos", es de nuevo la afirmación de los intereses de la Organización bajo la enseña del interés general. Tras las nociones de amparo y defensa de la comunidad, el movimiento se declara juez, guía y norte de los destinos de la zona. Difunde la idea de que lo que es bueno para las FARc es bueno para la comunidad. Veamos el contenido y el alcance de este Manual.

\section{UNA LEGISLACIÓN PARA LA SUPERVIVENCIA}

La introducción del Manual de convivencia lleva el tono amable y cálido de las conocidas disposiciones de avenencia y concordia difundidas en colegios, empresas y edificios de propiedad horizontal de los centros urbanos. ¿Cómo vivir en armonía con los demás? ¿Cómo favorecer las acciones dirigidas a la buena marcha de la colectividad? En la frase inicial las FARC invitan a los habitantes de las veredas a seguir las normas de entendimiento y fraternidad comunitaria para el "bien de todos".

Pero muy pronto el texto abandona el lenguaje afectuoso para adentrarse en el más crudo autoritarismo de vigilancia y mando, de intimidación y amenaza. E1 Manual no da respiro. Todo está reglamentado: el día y la noche, la mañana y la llegada de la tarde. No hay actividad que no esté bajo su mirada. Su vigilancia recuerda al Gran Hermano orwelliano, el poder omnipresente que todo lo dirige, ve y escucha; ojos que siguen a las personas donde quiera que estén y cualquier sonido más allá del susurro activa los controles de la Organización. En sus preceptos nada queda a la deriva y el único individuo que parece tener vida propia es el que está dormido (Orwell, 2016, 9 y 92).

teje un despotismo social que supera a muchas de las opresiones políticas conocidas (1969, 59-60). Los antecedentes intelectuales de esta crítica de la democracia despótica provienen de $\mathrm{El}$ Federalista n. $^{\circ}$ 51, donde se alude a los "proyectos injustos de la mayoría" y a la manera de limitarlos. Ver Hamilton et al. (1943, 226 y 227).

${ }^{12}$ FARC-EP, Manual de convivencia para el buen funcionamiento de las comunidades. Texto difundido por el Frente 32 del Bloque Sur de las Farc-Ep el 17 de noviembre de 2013 en las montañas del Putumayo. No sabemos si el Manual se hizo obligatorio en las demás regiones y frentes de las FARC o si solo fue una respuesta a las condiciones específicas del Putumayo. Se tiene conocimiento, sin embargo, de que sus disposiciones son atendidas en otras áreas farianas del país. 
E1 control brota en el primer artículo: “Toda persona mayor de quince años que viva en la vereda debe aparecer inscrito en el libro de socios de las Juntas de Acción Comunal”. Se informa, además, que no se permitirá en la región a personas que no presenten carta de recomendación de la Junta o del movimiento. Los que lleguen deberán permanecer un año en el vecindario sin salir a la cabecera municipal. A los vecinos que entren forasteros, así sean familiares, "se les hará un llamado de atención y el desconocido deberá salir”. La circulación de los antiguos está igualmente regulada. Todos aquellos que crucen los límites del caserío deben informar a la Junta cuánto tiempo permanecerán por fuera y la diligencia que van a hacer. En asuntos de transporte, se prohíbe la entrada de moto-taxistas, servicio que solo prestarán "reconocidos miembros" de la comunidad, esto es, adherentes de las FARC. Quien desee comprar un carro o una moto deberá consultarlo con las directivas del movimiento, y el desplazamiento a pie, en bestia o automotor solo podrá hacerse desde las cinco de la mañana hasta las ocho de la noche. Después nadie podrá moverse de sus hogares. $Y$ a las personas a las que se compruebe "que se han ido del área diciendo que el movimiento los ha desplazado, sin ser esto cierto, no se les permitirá el regreso a la zona".

El uso de celulares también está reglamentado. "Por medidas de seguridad solo se permitirá tener un máximo de dos aparatos por familia y no deberán tener cámara fotográfica". Los directivos de las juntas, "personas ejemplares en todos los aspectos", se encargarán de su debido control. Las fotos son un enemigo interno; podrían registrar vejaciones, rostros, caminos, plantaciones, campamentos, placas de vehículos, laboratorios de coca, etc. Y aún más. En los caseríos donde haya teléfono público se nombrará a un vecino de "confianza [para que lleve] un cuaderno de registro y control del nombre de las personas y de las llamadas recibidas y despachadas".

Los negocios y el desplazamiento de semovientes siguen la misma regla. El Manual señala que se deberá informar a la Junta toda acción de compra-venta de fincas, ganado, casas y demás bienes. Es necesario, además, presentar al comprador antes de llevar a feliz término la operación; quien se resista no podrá realizar la transacción. La movilización de ganado también está en el ojo del Manual. Deberá hacerse entre las 5:30 de la mañana y las 6:30 de la tarde, y los matarifes llevarán un cuaderno donde se registre el nombre de las personas a las que se les compró el ganado. Esto facilita el recaudo de vacunas en la carnicería y la exacción de aquellos que vendieron los animales para el sacrificio. 
Pero aquí no terminan las reglamentaciones farianas. E1 Manual anuncia que todo vínculo, directo o indirecto, de un habitante de la zona con la fuerza pública o con programas del Estado será castigado severamente. Aquellos que tengan familiares vinculados a organismos de seguridad del Estado, como el Ejército y la Policía, “deberán vender sus bienes y abandonar el área”. También prohíbe participar en programas oficiales como Familias en Acción -ayuda a familias desplazadas con niños y adolescentes- y Familias Guardabosques personas comprometidas con la erradicación de cultivos ilícitos y el desarrollo de productos agrícolas alternativos. Estos proyectos "van contra el pueblo". Para explicar el alcance de la amonestación, el Frente 48 "Pedro Martínez" del Putumayo acompañó la distribución del Manual con el siguiente volante:

Las FARC-EP piden a la población que no ingrese a estos programas gubernamentales Familias en Acción y Guardabosques porque ambos son de esencia contraguerrillera, es decir, contrainsurgentes, y por ello, la única y exclusiva condición para que puedas ser aceptado como beneficiario es que te conviertas en sapo o informante, llamados por el gobierno cooperantes.

Es bueno que analices la actitud malvada del gobierno. Primero te fumiga de manera intencional e indiscriminada la coquita, pero también la yuca, el plátano, el maíz, en fin, todo. Y después de que te ha dejado en la completa ruina, asfixiado por deudas y necesidades de toda índole, como se dice, sin tener donde caer muerto, entonces se te arrima y te ofrece un aparente "salvavidas": un miserable empleo cuyo objetivo fundamental es que te conviertas en enemigo de tu propio pueblo a cambio de un miserable sueldo.

Te invitamos a que ingreses a cualquiera de las estructuras organizativas de las FARC-EP. ¡Pueblo unido jamás será vencido!

Es claro que en este medio de intimidación permanente es muy difícil llevar a cabo el mensaje de Ulpiano: "Justicia es la constante y perpetua voluntad de dar a cada uno aquello que le pertenece, acción que hace que las leyes sean justas cuando sancionan esa voluntad"13.

Es claro además que las Juntas de Acción Comunal hoy ejecutan lo que ayer hacían las FARC de manera directa. Ahora las juntas son delegatarias de una autoridad enojosa y molesta. Los ideólogos consideraron que la Organización invertía demasiado tiempo y esfuerzo dirimiendo conflictos rutinarios -tensiones intrafamiliares, problemas de linderos, incumplimiento de obligaciones, daños a terceros, etc.- de gran significado para los implicados en las querellas, pero onerosos para el grupo armado que se desgastaba en acciones que le creaban ojeriza y encono en el vecindario. A juicio de sus dirigentes, las FARC debía guardarse para los casos difíciles, para conflictos que superan la

${ }^{13}$ El Digesto de Justiniano (1968, vol. I, 45-46). 
capacidad decisoria de las juntas y aparecer, sin mayores dificultades, como heraldos de paz y consenso comunitario ${ }^{14}$.

E1 Manual es una muestra de sus recursos judiciales dirigidos al manejo de las comunidades. Otra serie de documentos revelan su legislación en asuntos internos, aquellos que tienen que ver con el manejo de las huestes armadas, pero que en muchos aspectos vuelven a tocar las comunidades. No se debe olvidar que una guerrilla existe porque en derredor hay población que la nutre y asiste. Ella le provee su modus vivendi, abrigo y comida, y le facilita su modus operandi, sus acciones, su desplazamiento. movimiento armado que se aleje y se enajene el favor de los pobladores está perdido. Sería un vagar sin término por zonas inhóspitas. "Sin la población moriríamos de inanición”, apuntó un desmovilizado. Los vecinos salvaguardan la seguridad, facilitan el sustento y ayudan con el transporte de alimentos, ropa, armas y demás enseres de la cabecera municipal requeridos en los confines de la espesura. Y aún más, las comunidades ofrecen al movimiento la posibilidad de renovar sus efectivos. Una vez establecido en una región, toma y entrena niños y adolescentes para remozar sus contingentes. En pos de la perennidad se apropia y compromete a la próxima generación en los infortunios y desdichas de la guerra.

A la legislación dirigida al manejo de la Organización podríamos llamarla, con laxitud, derecho positivo interno de las FARC.

\section{DERECHO POSITIVO INTERNO}

Desde su fundación las FARc han sido muy dadas a legislar y a difundir códigos, estatutos y reglamentos. Sus dirigentes saben que quien aspire a dirigir grupos de algún tamaño debe seguir unas reglas que rijan la conducta del común. La improvisación permanente lleva al desconcierto y al caos, al terreno abonado del capricho y antojo de quien administra justicia. El Manual de convivencia es solo una muestra de este afán de formalizar la conducta de las masas bajo su tutela. Siguiendo el ejemplo de la sociedad mayor que intentan subvertir, fijan normas para regular la marcha de sus órganos armados y ordenanzas para regir las comunidades. Desean normalizar la dominación mediante pautas que eviten la arbitrariedad y el uso cotidiano de la fuerza. Saben que toda acción colectiva que no se oriente por

${ }^{14}$ En las entrevistas con desmovilizados de diversos frentes se señaló que los campesinos consideran una carga a las Juntas de Acción Comunal. Además de que los labriegos son tímidos y poco dados a reuniones y cargos de representación, son muy celosos con su tiempo. Deben atender las parcelas -animales y cultivos- y temen verse implicados en decisiones que podrían "molestar" a los vecinos, algunos de ellos parientes o amigos cercanos. 
preceptos generales, "para todos", lleva a la anarquía, y que la obediencia basada en la sola violencia encoleriza la mente y la voluntad de los vasallos. Para ello recurren a la sequedad del código y a la fría objetividad de la letra impresa. Este intento de racionalidad formal la aleja del tipo ideal del cadí, pero su aplicación -como se verá- no escapa a las prácticas irracionales y antiformales de una justicia con arreglo a valores últimos de carácter ético y político: la "revolución".

La codificación más relevante de las FARC se encuentra en un opúsculo de 110 páginas que contiene los principales estatutos, reglamentos y normas internas ${ }^{15}$. Su tamaño, siete centímetros, facilita su camuflaje, transporte y consulta en el campamento, en la casa del miliciano o en la morada del militante del Partido Comunista Clandestino. Apenas ocupa espacio en el morral del combatiente o en la mochila de los simpatizantes. Quien lo porte y caiga en manos de una patrulla del Ejército o de la Policía puede ser detenido e interrogado por varias horas. Como el misal del devoto, expone la doctrina esencial de la Organización. Su función es disciplinar las tropas guerrilleras y difundir los mandatos de la Organización en las comunidades bajo su influencia a fin de que no se invoque la vieja tesis de que la ignorancia de la ley exime su cumplimiento. También se puede consultar por internet, pero como en las montañas está prohibido usar teléfonos inteligentes, o no llega señal de comunicación alguna, la edición impresa es la más recurrida. Su articulado estipula la conducta esperada y el procedimiento a seguir para castigar a quien lo infringe. En apretada prosa combina el ordenamiento material (sustantivo) con el procesal (la forma de aplicarlo).

El opúsculo trae, además, el himno de la Organización, que exalta el ánimo de los combatientes, definidos como una cofradía de elegidos destinados a ennoblecer y salvaguardar al "pueblo":

Guerrilleros de las FARC

con el pueblo a triunfar

por la patria, la tierra y el pan...

Y para ratificar su entusiasmo y fervor en la lucha, una segunda estrofa pregona la realización de una utopía que anuncia un porvenir de armonía, bienestar y concordia:

Del imperio brutal ya se siente el final

con los brazos de América toda;

a los pueblos la paz y la felicidad

socialista el futuro será (cursivas del autor).

${ }^{15}$ Ver fARC-EP, Fuerzas Armadas Revolucionarias de Colombia, breviario que reúne siete documentos de interés jurídico.

Revista de Economía Institucional, vol. i9, n.o 36, Primer semestre/2oi7, Pp. 95-i 48 
Para una mayor comprensión del espíritu de la organización, debemos examinar ahora sus estatutos, su régimen disciplinario y sus normas de comando. Están centradas en el combatiente, pero -como se lucha por el "pueblo"- la comunidad siempre aparece en sus articulados.

\section{El estatuto de las farc}

La norma fundamental de las FARC, su "Carta”, se encuentra en una sección del opúsculo titulada Estatuto de las Fuerzas Armadas Revolucionarias de Colombia. El articulado define sus fundamentos ideológicos, su estructura orgánica, el régimen de los comandos y los deberes y derechos de los combatientes. Es ante todo un código de justicia militar redactado por una comisión cuyo borrador fue aprobado por una de las conferencias guerrilleras nacionales, la instancia superior de las FARC. A estas conferencias -reuniones periódicas de los frentes- compete reformar, actualizar y adecuar a las nuevas situaciones sus disposiciones de sabor jurídico.

Las FARC nacieron de los reductos de guerrillas liberales en regiones pobladas por colonos. Se desplazaron a la jungla como resultado de las incursiones del Ejército en sus asientos originales, las "repúblicas independientes". Con los años, medio siglo de actividad, fueron ganando terreno en regiones apartadas de la geografía nacional, especialmente en aquellas donde no había presencia del Estado. En su expansión crearon comunidades o se entronizaron en las existentes para quedarse, para vivir en ellas y de ellas. Cometieron secuestros y extorsiones, robaron ganado, fijaron "vacunas" y comerciaron con droga. Hicieron proselitismo con las armas en la mano y administraron justicia -orden y consenso- mediante la persuasión, el hechizo y la intimidación. Se autodefinen revolucionarias en cuanto luchan por transformar la sociedad y hacerse al aparato del Estado por las armas. La violencia es su fuerza política. Si en pos de sus objetivos ven la posibilidad de intervenir en elecciones o negociaciones regionales, participan en la escogencia de alcaldes, concejales y funcionarios de los municipios bajo su influencia. Para las FARC el alzamiento armado no excluye la lucha política y el debate en la plaza pública. La divisa leninista: "la combinación de todas las formas de lucha”, les es muy querida. Aspiran al poder, es decir, quieren influir en los asuntos públicos por todos los medios. Consideran que si el Estado tiene sus oficinas electorales, su policía y su ejército, ellas -hasta donde lo permitan las circunstancias- también deben aprovechar las jornadas electorales al lado de sus escuadras. Se definen como Estado ambulante, como autoridad 
que emplea medios legales e ilegales para alcanzar obediencia en sus territorios. Todo esto se anuncia en los artículos iniciales del Estatuto:

Las Fuerzas Armadas Revolucionarias de Colombia, Ejército del Pueblo, la expresión más elevada de la lucha revolucionaria por la liberación nacional, son un movimiento político-militar que desarrolla su acción ideológica, política, organizativa, propagandística y armada de guerrillas, conforme a la táctica de combinación de todas las formas de lucha de masas por el poder para el pueblo [...] Aplican a la realidad colombiana los principios fundamentales del marxismo-leninismo [y] se inspiran en el pensamiento revolucionario del Libertador Simón Bolivar ${ }^{16}$ (cursivas del autor).

Para el observador externo no es clara la noción de "liberación nacional". ¿De qué poder extranjero quieren liberar las FARC a los colombianos? La independencia de la Corona española se logró durante las primeras décadas del siglo xix y desde esos años el país no ha sufrido invasión alguna de su territorio que haya dado lugar a la desaparición de sus instituciones jurídicas y políticas. En la actualidad se rige por una constitución, un parlamento, unas cortes y un presidente elegido por la ciudadanía. Ante este hecho los ideólogos de las FARC emprenden un rodeo espoleado por su marxismo-leninismo. Colombia -afirman- es un país neocolonial, dependiente, con una

${ }^{16}$ Los documentos ideológicos de las Farc juegan con los conceptos de pueblo, comunidad y masa sin delimitación alguna. Unas veces los separan, pero en general los intercambian hasta convertirlos en sinónimos para hablar en nombre de todos - la mayoría- y apropiarse de su representación. En sentido estricto, comunidad alude a la población que ocupa un territorio cuyos miembros, con intereses materiales y espirituales semejantes, establecen vínculos permanentes que avivan un sentimiento de identidad y pertenencia. En su interior hay ricos, pobres y sectores medios. Las comunidades dominadas por las FARC son, la más de las veces, inestables, de frontera, de colonización reciente que no va más allá de una generación. El negocio de las drogas y de la minería ilegal las ha hecho muy fluidas, creando un escenario donde entra y sale mucha gente con redoblados bríos. Las comunidades más apreciadas por las FARC son aquellos vecindarios estables donde sus miembros han militado por varias generaciones en sus filas. Pueblo, palabra que nutre la divisa EP que llevan sus huestes en el brazo, es noción elusiva. Unas veces alude a los habitantes de un país (el pueblo colombiano), otras a la cabecera municipal (los que viven en el pueblo), otras a los moradores de una vereda (la comunidad como tal), y otras más, el caso más recurrido, a los pobres del campo de Lenin -los económicamente débiles de Weber- que en el caso colombiano adquieren la silueta del minifundista, el peón, el trabajador asalariado de las fincas y minas de oro y plata, sin dejar de lado al "raspachín", la mano de obra itinerante de los apreciados y vilipendiados cultivos de coca. Masa es, por lo demás, vocablo amorfo que anuncia cierta unidad en un conglomerado de hombres y mujeres. Las FARC lo usan para orientar su labor ideológica en la población bajo su influencia: el "trabajo de masas". Visitar las familias, ganar su confianza, escuchar sus dificultades y hacer reuniones con los vecinos para difundir el evangelio del movimiento y solucionar problemas comunitarios: arreglo de caminos, conducción de aguas para los regadíos, arreglo de la escuela, modernización de las viviendas, etc. De la efectividad del trabajo de masas depende la colaboración de la gente con la guerrilla. Es labor persuasiva para limar la brusquedad de la ostentación cotidiana de las armas. 
clase dirigente inclinada ante los intereses políticos, económicos y estratégicos del imperialismo norteamericano. Es necesario acabar esta influencia para alcanzar la libertad y despejar la llegada de la sociedad socialista anunciada en la romanza del movimiento.

Las FARC son una institución jerárquica. En la cima se encuentra el Estado Mayor Central y a su lado el Secretariado. E1 Estado Mayor (de 31 miembros) legisla, es la instancia jurídica por excelencia, y el Secretariado, elegido por el Estado Mayor, ejecuta. Envía las circulares, "la línea política", a todas las regiones donde hay frentes y puestos de lucha. El Secretariado lo integra un reducido número de personas (9 miembros) y se reúne con más frecuencia que el Estado Mayor. Así, el poder de la organización recae en sus manos. Allí los fundadores, los “viejos”, Manuel Marulanda o Jacobo Arenas por ejemplo, tenían autoridad e influjo especiales. Quienes llegan al Secretariado tienden a permanecer en el cargo hasta el final de sus días. Solo la deserción, la muerte, la enfermedad o el envío a tierras lejanas los marginan de esa posición. Es la cúspide de la movilidad social dentro de la organización. Cuando mueren en combate o por causas naturales, se convierten en héroes, en imágenes ejemplares de un santoral que adorna hombros, camisetas, afiches y carátulas de libros y folletos con emblemas como el de "comandante Jacobo Arenas, estamos cumpliendo". E1 Secretariado controla la vida del movimiento. Nombra la dirección de los frentes, autoriza o niega la salida a la ciudad de los mandos medios para descanso, atención médica o desarrollo de tareas especiales, y define los casos de ajusticiamiento (artículo 3). Es la última instancia en asuntos procesales. A los miembros del Secretariado les llega el prontuario del reo, lo discuten y a poco autorizan su desaparición o liberación. Las FARC no tienen cárceles. Como la comunidad zíngara, siempre están en movimiento. Procesan con celeridad y con igual celeridad se desembarazan del "malhechor"17. Pero no todos los casos llegan al Secretariado. Generalmente los detenidos son ajusticiados por los frentes y apenas se envía un parte a las instancias superiores. Esto ha dado lugar a "errores", al fusilamiento de inocentes o la ejecución de personas de valor estratégico para una eventual negociación con el Estado o con otros países cuando se trata del secuestro de extranjeros.

E1 Estatuto señala que las FARC se componen de combatientes que se "unen conscientemente a la lucha armada" y que a su regazo se llega por tiempo indefinido, "hasta el triunfo de la revolución”. Se sabe, sin embargo, que el reclutamiento forzado de niños, adolescentes y adultos

${ }^{17}$ Las "cárceles" de las FARC son encierros, apriscos de alambres de púas inmersos en la jungla para albergar secuestrados en espera del pago de su "retención" o de la negociación de prisioneros con el Estado. 
es corriente. No se llega a ellas por adhesión y elección del corazón. Generalmente toma la forma de invitación a jóvenes sin perspectivas ocupacionales de pueblos y veredas bajo la presunción de que en sus filas encontrarán oportunidades de progreso económico y de promoción social y cultural. Es frecuente el reclutamiento de jóvenes que desean liberarse del autoritarismo de su grupo familiar o, en el caso de las jóvenes, de la agresión sexual de padres, tíos, padrastros y hermanos mayores. Pero con el paso de los días advierten que están sujetos a una autoridad férrea que supera la férula del hogar abominado de la que querían escapar. Quien se suma a su trajín entrega su existencia al llamado de "color oscuro" estampado en la portada del averno de Dante: "Los que aquí entráis, perded toda esperanza y todo sentimiento de temor y cobardía" ${ }^{18}$. El recién entrado se aísla de la sociedad mayor para ingresar a un mundo de recogimiento benedictino de entrega y renuncia similar a la del monje medieval. Su destino, su presente y su futuro estarán sellados mientras permanezca bajo su abrigo. La Organización se convierte en su nuevo modo de vida, en una institución total donde el joven encuentra comida y vestido, amigos, solidaridad, protección y apoyo ${ }^{19}$.

Para afianzar este sentimiento de pertenencia, en el imaginario de los combatientes ronda una máxima que aprenden en los primeros

18 Alighieri (1982, canto III, versos 9 y 14-15).

${ }^{19}$ Las instituciones totales son lugares de residencia, vida y trabajo, donde un buen número de personas aisladas de la sociedad por largo tiempo comparte -en enclaustramiento- una rutina diaria bajo normas de vigilancia y control. Cárceles, conventos, cuarteles, campos de concentración, internados escolares, lazaretos y asilos de ancianos y de enfermos mentales, como Sibaté, son los ejemplos más conocidos. Es el grupo primario actuando sin cortapisas. Estos arreglos institucionales conforman un universo propio que absorbe el tiempo y los intereses de sus miembros. Todos se conocen y entre ellos no hay secretos. Trabajan, duermen, comen juntos y suelen vestir de la misma manera, uniformados. Se ven a diario y en sus perennes interacciones se confiesan su pasado y las razones que los llevaron a ingresar a la institución, unas veces por elección, otras por coerción externa o por una combinación de una y otra. El éxodo - la salida- está reglamentado, cuando no expresamente prohibido. Se abandonan sus muros porque se ha cumplido el tiempo de reclusión prescrito, porque el enfermo se ha curado, porque media una aquiescencia (un permiso), porque el ciclo educativo que lo condujo a su retiro ha terminado o porque el comando de un grupo guerrillero firmó la paz con las autoridades que buscaba derrocar en la guerra. La evasión, la muerte o la liberación del cautivo, de un secuestrado por ejemplo, son casos límite y extremos. Los sobrevivientes de Auschwitz afirmaban que solo se salía del campo de concentración por el humo que salía de los hornos crematorios. La naturaleza tiránica de las instituciones totales, su tendencia a manejar la vida entera de las personas, se expresa en el paisaje que siega las relaciones con el exterior: paredes, centinelas, puertas cerradas, alambradas de púas o, aún más, establecimientos situados en islas o regiones apartadas e inhóspitas rodeadas de selva, pantanos, acantilados y ríos caudalosos. Ver el texto clásico del canadiense Erving Goffman (1973, 13 y 17-20). 
días de clausura: "Las FARC son un bus que se detiene para recoger, jamás para dejar". La cual es reforzada por una segunda sentencia que anuncia el acatamiento de marchar al paso: "Quien ingresa a las FARC se educa, se va o se muere". Acepta las reglas, deserta o perece por obstinación, repulsa y porfía. Aprenden que la disciplina en las FARC es político-militar, un orden que se rige por un código de supervivencia, de vida o muerte, un precepto de acatamiento interno y camuflaje externo ${ }^{20}$.

Ese proceso dificulta su resocialización una vez desertan o son capturados por el Ejército. Nada o poco saben aquellos jóvenes de la sociedad por la cual dicen luchar y que buscan transformar hasta entregar su propia vida. Su vivencia guerrillera los ha separado de la ciudad, de sus hábitos y de sus instituciones. Son torpes en las labores escolares asociadas a la lectura y la escritura, lerdos en el manejo del dinero y el uso de los servicios públicos, para no mencionar la comprensión de libros, periódicos y revistas. Hablan un idioma pobre, una lengua de tono campesino y provinciano, con giros y dejos que sorprenden al citadino y acentúan su timidez ante los retos de la metrópoli. Mientras que el campo es paisaje, naturaleza viva, despejada y abierta, la gran ciudad es brusca, un ámbito artificial de oficinas, comercio, industrias, autos y calles bulliciosas donde la gente circula con apuros y escasas relaciones de calidez, colaboración y ayuda con el vecino. Abandonar los marcos guerrilleros es como salir de una abadía después de décadas de encierro para enfrentar un medio anónimo de desconfianza, lejanía y esquivez. Ha finalizado la solidaridad del grupo primario; ahora es el yo solitario y libre afirmándose en un universo de rivalidad y competencia afincado en las capacidades personales, que son pocas cuando se ha gastado demasiado tiempo en la selva ${ }^{21}$.

20 Entrevistas con desmovilizados.

21 A quien entrevista desmovilizados le impresionan su timidez, recelo e inseguridad. Son personas calladas, solitarias; jóvenes, hombres y mujeres en espera recelosa de lo que traerá el mañana. Temen que les haga daño un miliciano por haber abandonado el grupo armado o que su familia y antiguos amigos sean intimidados. Dicen apenas lo preciso, rara vez narran todas sus experiencias o relatan sus desdichas, infortunios y alegrías. Buena parte ingresó a las guerrillas en los días en que se marchitaba la niñez y afloraba la adolescencia. Abandonaron las filas al cumplir 18, 20 o 24 años, y sus caras, lustradas por la intemperie -la selva, la lluvia, el sol y el frío- revelan una edad que no es la suya. Aparentan unos treinta y su comportamiento es el del adulto, de la persona que desea manejarse por sí misma sin pedir ayuda a los demás.

El futuro y la familia nutren su incertidumbre. Todos evocan el calor de la estirpe, pero sospechan que muchas cosas han cambiado. Se fueron a la guerrilla para evitar la opresión y el ahogo de adultos abusivos y despóticos y ahora, ya "mayores" y experimentados, los carcome la nostalgia de los abuelos, la madre, el padre y los hermanos menores. No saben muy bien qué encontrarán a su llegada ni si aún hay hogar al cual regresar. Sienten, además, que su mayor vacío es la 
Regresando de nuevo al Estatuto, se debe apuntar que los deberes del combatiente de las FARC están asociados a nociones de unidad, armonía, fraternidad y solidaridad de grupo. El llamado es directo: en la lucha entre el yo y la colectividad, ponte de parte de ella. El deber es mantener en alto el movimiento, lo demás es adjetivo y puede esperar. El Estatuto exige a sus efectivos honestidad y modestia; veracidad, abnegación y pruebas de firmeza ante el enemigo, reserva del secreto guerrillero y cumplimiento de las órdenes para llevar a feliz término las determinaciones de los comandantes (art. 7) ${ }^{22}$.

En medio de estas constantes exigencias el Estatuto no se olvida de los derechos de los miembros. Promueve la crítica "constructiva", aquella que busca mejorar el movimiento señalando errores y faltas en la conducción de las tareas. Festeja la participación en las discusiones y las posibilidades de elegir y ser elegido a cargos de representación. Exalta los estímulos políticos y morales y el acceso a niveles de responsabilidad. Es de observar, sin embargo, que todas estas libertades y derechos se permiten si van en bien de la Organización y no desbordan el marco del poder central, pues las FARC, como las demás organizaciones guerrilleras, son muy sensibles a las manifestaciones de insubordinación. Su política se funda en el temor a las sublevaciones. No soportan los alzamientos internos, y cuando brotan surge el escarnio, la supresión rápida de la herejía y la desaparición del rebelde. El Estatuto subraya y recalca "mantener una actitud vigilante en defensa de la unidad del movimiento y desenmascarar oportunamente

falta de educación formal. Muchos carecen de los rudimentos del alfabetismo y añoran terminar su enseñanza primaria para ingresar a la secundaria. Piensan que el éxito reside en la escuela y el colegio, a los que definen como el vehículo que los conducirá por la senda del progreso social, a una ocupación estable con ingresos decorosos. Muchos tienen familia a edad temprana. Jovencitas de 17, 18 y 20 años trajinan con vástagos en sus brazos. Unas tienen su cortejo al lado, otras están solas. Su compañero no pudo desertar o se fue a una región desconocida. Hay jóvenes que entregaron sus hijos a los abuelos, los padres o a tías dedicadas y jamás volvieron a verlos. No pocas desertaron para salvar su embarazo de los temidos legrados guerrilleros. No escasean los desmovilizados con laceraciones en su cuerpo. Exhiben cicatrices y amputaciones, cojean y revelan limitaciones de visión y oído o muestran síntomas de leishmaniasis mal tratada. La guerrilla carece de programas de seguridad social durables, y los amputados son una carga, "prescindibles" que todos miran con desazón y enfado.

${ }^{22}$ Esto hace que en muchos aspectos la guerrilla se comporte como una "persona colectiva" que absorbe las individualidades que la conforman para fundirlas en una sola entidad, en una comunidad de ánimo, como le gustaba decir al jurista y sociólogo Otto von Gierke. Se espera que el derecho de las FARC, su codificación, contribuya a cristalizar la aclamada hermandad de acción y sentimiento de sus miembros. Este rasgo, tan afín al talante de las instituciones totales, encuentra en el movimiento guerrillero - un modo de vida de apoyo mutuo para escamotear al enemigo- una exaltación particular. Ver el sugerente ensayo de Erik Wolf (s. f., 90-93). 
el trabajo de zapa y el espionaje del enemigo". Como toda sociedad secreta, las FARC promueven la revolución en el entorno, pero no admiten levantamiento alguno en su interior.

Pero en el realce de las prerrogativas y obligaciones del combatiente, el artículo 8 del Estatuto trae una perla ideológica de no fácil digestión: "Los deberes y los derechos en las FARC-EP son iguales para todos sus integrantes pero sin igualitarismo pequeño burgués". ¿Qué significa esto?, ¿que todos sus miembros son semejantes pero que unos mandan y otros obedecen?, ¿que unos disponen y otros laboran?, ¿que unos tienen exigencias y otros deberes y responsabilidades? Esto recuerda las agonías de Orwell en el capítulo final de la Rebelión en la granja: “Todos los animales son iguales, pero algunos animales son más iguales que otros" $(1999,121)$. ¿Qué idea de igualitarismo imputan las FARC a los miembros de la petite-bourgeoisie? ¿La igualdad aritmética de que unos y otros hacen las mismas cosas en conformidad y consonancia?, $¿$ ¿que quien dirige es dirigido y quien manda obedece? Este igualitarismo no parece estar en el proyecto de las FARC, una organización jerárquica. Es además ingenuo pensar que la pequeña burguesía, un grupo social tan diverso y estratificado que rara vez alcanza una identidad de clase con intereses homogéneos -comerciantes modestos, artesanos de la ciudad y del campo, medianos propietarios urbanos y rurales, maestros, militares y profesionales universitarios, funcionarios del Estado y de las grandes empresas que viven de un salario-, comparta el mismo ideal de igualdad. El observador desearía que la claridad de los ideólogos de las FARC fuera tan concluyente como su entusiasmo por cambiar el mundo ${ }^{23}$.

A pesar de los denuestos contra los sectores medios, en su Programa agrario, incluido en el venerado opúsculo que los militantes

${ }^{23}$ Pese a que un número apreciable de sus dirigentes proviene de sectores medios, las FARC carecen de una teoría de su lugar y papel en la sociedad. Cuando se refieren a ellos con el mote de "pequeña burguesía" anuncian, en general, una valoración negativa de la población activa que se halla en una posición intermedia entre la gran burguesía -terratenientes y grandes capitalistas comerciales e industriales- y el proletariado. Desconfían de ella. Con Engels, la encuentran "humilde y lacayuna" ante los poderosos y portadora de "la más abyecta cobardía tan pronto como la clase que está por debajo, la de los proletarios, intenta un movimiento independiente" (Engels, 1973a, 311-312 y 387-390).

A la pequeña burguesía no le fue mejor en el Manifiesto comunista. Los estratos medios -apuntaron sus autores- luchan contra la burguesía para salvar el pellejo ante su ruina inminente, no para transformar la sociedad. "No son revolucionarios sino conservadores; aún más, son reaccionarios, tratan de hacer girar hacia atrás la rueda de la historia"; quieren salvar el antiguo estado de cosas ante el ímpetu de la industria, que todo lo destruye en derredor. Tales sectores -añadieron- no se dan cuenta de que la nueva sociedad, la burguesa, "ha convertido en sus obreros asalariados al médico, al jurista, al cura, al poeta y al hombre de ciencia” (Marx y Engels, 1998, 42 y 52). 
portan en sus mochilas, las FARC invitan -junto a obreros y campesinos- a empleados, estudiantes, artesanos, intelectuales, pequeños industriales, medianos comerciantes y burguesía nacional, a unirse "a la gran lucha revolucionaria”. No es claro qué está detrás de la idea de "burguesía nacional", noción tan recurrida por el marxismo latinoamericano de mediados del siglo xx. Quizá aluda al sector de la clase alta que se siente "oprimida" (limitada en sus negocios) por la competencia "desleal” de la economía global regida por las grandes potencias. Las FARC esperan que esos capitalistas endógenos se unan a la lucha contra el imperialismo en pos de "un gobierno democrático de liberación nacional”. Pero los sectores ilustrados de esta burguesía, sus asociaciones gremiales y sus organismos políticos saben bien que una vez triunfe la guerrilla, su compañero de viaje, "el grupo armado del pueblo", cavará su sepultura.

El Estatuto no habla de ejecución o de otras opciones letales. Solo menciona un furtivo "ajusticiamiento" sin mayores explicaciones (art. 3). Es evidente que una mención de esta índole en la Carta no sería de buen recibo en los organismos de derechos humanos. Para el derecho estatal, que prohíbe la pena de muerte, una ejecución es barbarie y una desaparición asesinato, homicidio intencionado. Pero en las FARC, como en el crimen organizado, la ejecución de personas es un asunto corriente. Se la realiza en las proximidades del campamento o en las calles de las cabeceras municipales cuando se "caza" al desertor, al traidor o al informante. $Y$ cuando se trata del morador que se resiste a abandonar la comunidad, se recurre al sombrío mutismo de la desaparición en acantilados o ríos caudalosos ${ }^{24}$.

\section{El reglamento de régimen disciplinario}

Pero si el Estatuto es elusivo con el ajusticiamiento, otro código, el Reglamento de régimen disciplinario de las farc, es explícito y directo. El Reglamento es su instrumento de justicia penal militar y allí aparece el fusilamiento sin fingimientos como acción directa y ejemplar. E1 artículo 4 señala:

El fusilamiento [se llevará a cabo] solo en caso de extrema gravedad, como la traición, la delación y otras formas de colaboración voluntaria con el enemigo, el asesinato de compañeros de filas o de las masas, la deserción con armas o dinero del movimiento y otros delitos de acuerdo con su gravedad.

En las FARC, como en las demás organizaciones clandestinas, donde el secreto es obligado, se aplican con generosidad la intimidación y la tortura. El caso más conocido es el de la masacre de finales de 1985

\footnotetext{
${ }^{24}$ Entrevistas con desmovilizados.
} 
y principios de 1986 en Tacueyó, un corregimiento del municipio de Toribío en el departamento del Cauca. El exterminio fue ordenado por el Frente "Ricardo Franco", un grupo disidente de las FARc liderado por alias "Javier Delgado", conocido como el monstruo de los Andes. Delgado, un hombre de confianza de Jacobo Arenas del Secretariado de las FARC, se fugó con un millón de dólares para crear su propia guerrilla. A los pocos meses se tomó un pueblo, Miranda, donde se incorporó a sus filas un grupo amplio de personas. "Ahí comenzaron los problemas”, apuntó un sobreviviente. Se dijo que entre los recién ingresados había cinco infiltrados. Empezaron a desaparecer personas. Al principio una, luego otra y después muchas más. Las sacaban en grupos y las llevaban a los campamentos "donde bajo tortura, unos aventaban a otros, y así se fue haciendo interminable la lista de supuestos infiltrados”. En total se asesinó a 164 personas entre hombres, mujeres y niños. La mayoría de ellos jóvenes campesinos que habían ingresado al Frente "porque se decía que allí había plata y buenas armas". Se encontraron cuerpos a los que se había abierto el pecho aún con vida para extraerles el corazón. Algo semejante ocurrió con tres cadáveres de mujeres embarazadas, con los vientres vacíos, y varios hombres enterrados vivos, todos ellos mutilados. Delgado desapareció, pero fue capturado en 1995 en un operativo contra el cartel de Cali, para el que terminó trabajando. Fue condenado a 19 años de prisión por rebelión y por la masacre de Tacueyó, pero no llegó a cumplir la condena. En junio de 2002, el Pol Pot colombiano fue ahorcado en su celda de la cárcel de máxima seguridad de Palmira por un comando de las FARc (Semana, 2006 y 2014). Las FARc, en una acción de vendetta, lo eliminaron por robo de dinero, por su entrega al narcotráfico y por "desviarse" de la lucha revolucionaria.

El ajusticiamiento por matar compañeros es corriente. Un caso ocurrido en el Caguán en 2014 llenó de espanto a la comunidad guerrillera. Un joven celoso que convivía con su amiga, la encontró departiendo animada con un compañero de la misma columna. La ira de Otelo emponzoñó su corazón, cargó el arma y mató al camarada. Se lo llevó a juicio y fue ejecutado. La joven, desolada y con un lacerante sentimiento de culpa, desertó en busca de un mundo distinto. En el incidente la guerrilla perdió a tres combatientes experimentados, y la amante a dos admiradores de apenas más de veinte años. A cambio, la sociedad mayor se hizo a una joven que dejaba atrás un pasado de tristura para enfrentar un futuro colmado de incertidumbres ${ }^{25}$.

${ }^{25}$ Entrevistas con desmovilizados. 
Estas prácticas aciagas contrastan con la cálida retórica del párrafo inicial del Reglamento:

La disciplina proletario-militar para quienes se han agrupado en la lucha armada contra el régimen oligárquico y la dominación imperialista yanqui por un gobierno patriótico de liberación nacional, es una necesidad y por tanto es consciente, firme y seria. Es una disciplina militar de nuevo tipo, que nada tiene que ver con los métodos brutales y disciplinarios que se aplican en los cuarteles del ejército burgués. La observancia y cumplimiento de la disciplina proletario-militar es un honor para todo combatiente de las farc-ep (cursivas del autor).

En pocas palabras, la obediencia en el ejército oligárquico es opresión, vejamen y desdicha, y la sumisión en las FARC es liberación y fuente de prestigio. Sus ideólogos, laxos con el idioma cuando amparan su perspectiva, parecen olvidar la advertencia de Engels: "autoridad quiere decir imposición de la voluntad de otro a la nuestra, [lo que] supone subordinación" (Engels, 1973b, 397) ${ }^{26}$.

La disciplina clandestina es aún más severa. Para alcanzar los objetivos de la agrupación se exige la más estricta uniformidad en el proceder de los asociados. Desaparece la voluntad individual y todo reclamo particular. En su interior la vida se traduce en mandar y obedecer, en obediencia uniforme para "crear íntima cohesión y unidad política" y llevar a cabo las tareas emanadas de los órganos superiores. Es aquí donde el Reglamento expresa sus mandatos con mayor claridad. Toda infracción disciplinaria - manifiesta- es objeto de castigo, suave o enérgico, según se trate de faltas o de delitos. Una falta es una negligencia, y una contravención que afecta la vida del grupo es un delito. $\mathrm{Su}$ artículo 3 es generoso en el enunciado de estos últimos: asesinato de compañeros o de personas de la población civil, deserción con el arma o sin ella, apropiación de fondos del movimiento, revelación de los secretos de la cuadrilla, abandono del puesto de guardia, violación sexual, consumo de licor y de estupefacientes, "chismografía" (hablar mal de los compañeros) y, especialmente, fraccionalismo. Este último, manifestación de cisma, división y herejía para las FARC, es severamente castigado. Pone en cuestión su unidad y, según su laya y condición, recibe el odiado mote de uno de los tres ismos más abominados por la izquierda de pigmentación marxista: divisionismo, revisionismo, desviacionismo.

Las faltas tienen su gradación: leves, graves de primera instancia y graves de segunda instancia. Las leves, "las que se cometen sin in-

${ }^{26}$ Las meditaciones de Weber sobre el significado de la disciplina, definida como "la uniformidad de la obediencia por parte de una multiplicidad de hombres", son igualmente instructivas. En su exposición hay más de una afinidad con el enfoque de Engels, a quien parece haber leído y desarrollado con mayor extensión. Ver Weber (2014, 1135-1149). 
tención de causar daño a los compañeros o al movimiento", se tratan con llamadas de atención. Si se hacen reiterativas pueden alcanzar el calificativo de "graves", paso nada fácil de determinar en la práctica. Aquí los comandantes tienen la palabra. Las instancias de las faltas graves son igualmente difusas. No es seguro si por instancia se entiende el peso de la falta, las etapas de un proceso judicial o simplemente la autoridad que atiende un asunto según la gravedad de la infracción (la instancia competente). De hecho, parece ser la combinación de todas ellas al momento de evaluar las particularidades de la negligencia objeto de castigo.

Las faltas graves de primera instancia abarcan la irresponsabilidad, la pereza y la cobardía; las riñas entre combatientes; la mentira para justificarse ante los superiores; la calumnia, la ausencia de compañerismo y la desmoralización (laxitud en la disciplina). Las graves de segunda instancia están asociadas con el empleo de palabras soeces contra jefes o camaradas, el uso de apodos denigrantes, el irrespeto a los comandantes, los juegos de azar y la embriaguez recurrente, la simulación de enfermedad para eludir tareas y el empleo de armas como diversión. Muchas de estas faltas no son de fácil definición y su calificación, en la práctica, recae en los superiores.

Un episodio de embriaguez ilustra la elasticidad de las sanciones. Un militante comunista, Alvaro Delgado, que viajaba por la región de El Pato (Huila) en los años ochenta, se topó en su camino con una fiesta campesina que duró tres días con sus noches. Había mucho licor y comida, los combatientes de la zona miraban el certamen con deseos de integrarse, pero las normas establecían que si un guerrillero quería participar en los jolgorios debía ceder el arma a un camarada, ya que estaba prohibido bailar con el fusil terciado. Al segundo día, sin embargo, uno de los comandantes, Óscar Reyes, se emborrachó, "comenzó a saltar como un mico y de pronto sacó la pistola e hizo varios tiros al aire. Esa era una falta grave, y someter al hombre, que era una persona violenta incluso estando sobrio, fue toda una odisea y un ejercicio de valentía y paciencia de sus compañeros. El tipo fue sancionado y alejado del lugar". El viajero no describió la sanción, pero no parece haber sido demasiado drástica ya que no fue retirado de la Organización ni su vida se puso en peligro. El estatus de comandante aminoró el castigo, que sin duda habría sido más riguroso en el caso de un guerrillero raso; es un ejemplo más de la "consideración a la persona" de Weber (Delgado, 2007, 237) ${ }^{27}$.

27 Delgado agregó: "En los años siguientes [Reyes] siguió observando mal
comportamiento y supe que lo habían sacado de la región. Posteriormente los 
Las sanciones a que dan lugar las faltas son impuestas por los jefes de la columna a la que pertenece el inculpado o por la guerrillerada, la asamblea de combatientes. Generalmente es sanción colectiva y ejemplarizante que termina en la crítica y autocrítica del acusado ante los colegas. Es justicia expiatoria dirigida a reparar en la conciencia del procesado una conducta considerada alevosa y pérfida. $\mathrm{Si}$ la sanción está dirigida a un cuerpo -una célula o personas a las que se encomendó un trabajo-, la pena es asunto de los estados mayores. Aquí se cambia de instancia punitiva. En las infracciones calificadas de delito se recurre a los mismos castigos de las faltas graves, pero con un énfasis más inflexible y ejemplar. Si lo investigado reviste un peligro mayor se recurre a un organismo más complejo e intimidante: los consejos revolucionarios de guerra.

Los consejos de guerra calcan algunos procedimientos formales, no todos, de los juicios en el derecho estatal. La asamblea de guerrilleros elige un presidente, un secretario, un fiscal y un jurado que escucha y valora lo sucedido. Se espera que el jurado sea la manifestación de la "conciencia" de los combatientes. El convicto nombra un defensor entre sus colegas, por lo general un amigo de especiales dotes razonadoras, para que exponga su tropiezo y frene el ímpetu del fiscal. A continuación viene una doctrina procesal penal sui generis. El jurado, por mayoría, condena o absuelve y luego somete su decisión a la asamblea. La guerrillerada, la comunidad de vida del grupo, lo ratifica y si lo encuentra improcedente lo devuelve a los miembros del jurado para su modificación. "Quien falla en definitiva -dice el Reglamentoes la asamblea”. Es, en síntesis, justicia por aclamación, manifestación de justicia popular que recuerda las prácticas del primitivo derecho germánico donde se juzgaba por ovación. El carácter de institución total de las cuadrillas -todos se conocen y saben cómo es y cómo ha sido su compañero de lucha en las "buenas y en las malas"-facilita el dictamen final. Los odiosos, mezquinos y antipáticos tienen dificultades y a los más queridos se les da una segunda oportunidad ${ }^{28}$.

periódicos informaron que había sido detenido en la Costa Atlántica y que había enloquecido en la cárcel".

${ }^{28}$ Al iniciar el juicio, el presidente o el secretario recuerdan los pasos a seguir según establece el Reglamento. El secretario lleva un cuaderno y registra los incidentes del proceso y el nombre del implicado. No tenemos noticia de la suerte de esos cuadernos y menos aún de la extensión de los testimonios consignados en sus páginas. Sospechamos que son muy escuetos y no se sabe si las sentencias se archivan en un libro o en un computador para custodiar la memoria de la actividad judicial de la Organización. La guerrilla se mueve sin descanso y no debe llevar consigo documentos que mañana puedan caer en manos del enemigo e incriminar al grupo. Lo usual, sin embargo, es la existencia de una cultura oral en asuntos judiciales. Se dice que cierto caso se juzgó de esta manera y que uno 
La gravedad de un delito, su calificación, no es siempre rigurosa, en especial cuando no aparece enunciada en el Reglamento o cuando las "lagunas", el silencio de la ley, no of recen orientaciones seguras para atender la diversidad de casos. Su determinación exige interpretación y un volver atrás para compararlo con experiencias del pasado. Aquí la opinión de los jefes - la autoridad- es importante, pero también el clima de sospechas y temores del momento y la capacidad persuasiva de los acusadores y los defensores. Como se ha indicado, en los juicios cuentan mucho los antecedentes del "delincuente". Si se ha caracterizado por su entrega al movimiento, por su especial esmero en las tareas encomendadas y, sobre todo, por su voluntad de colaboración, ayuda y dedicación a los compañeros, la asamblea guerrillera lo puede salvar de la eventual ejecución. El buen revolucionario es aquel que sacrifica el yo por el tú, por los demás. "En este caso se le da otro chance" 29 .

Lo anterior sugiere que los castigos en las FARC tienen un amplio margen, desde las llamadas de atención hasta el fusilamiento. En este continuum hay una mezcla de lo formal y lo informal, de lo racional y lo irracional en la administración de justicia. Cada caso muestra la cercanía o lejanía respecto de la norma estatuida en el Reglamento. Como todo régimen disciplinario, es control objetivado, sucesión de mandatos impersonales dirigidos a orientar la conducta de los miembros de un grupo comprometido en operaciones encubiertas. De allí que las FARC pongan especial empeño en el adiestramiento físico y mental de los miembros que se inician en la "gesta del pueblo". Los dirigentes saben que solo es posible asegurar el ciego acatamiento de un grupo de jóvenes de catorce a veinte años cuando han hecho suyo el espíritu de un código de subordinación generalizada. Su letra facilita la formación del recién llegado, proceso que al traducirse en cartilla digerida, gana la mente del combatiente hasta modelar su personalidad en comportamiento uniforme. Si por dominación se entiende la probabilidad de encontrar obediencia en un grupo determinado de individuos, disciplina significa -según la prosa jadeante de Weber-la "probabilidad de encontrar obediencia para un mandato por parte de un conjunto de personas que, en virtud de actitudes arraigadas, sea pronta, simple y automática" (Weber, 2014,184). Para que se dé esto más de esta otra. Es un pasado fluido, de oídas; alguien lo relató y alguien lo escuchó, aunque a veces algún integrante del tribunal manifiesta haber participado en un proceso anterior. A pesar de estas lasitudes, los casos juzgados más difundidos y escuchados en las cuadrillas, que nutren el imaginario de los jóvenes combatientes, son usados para orientar las decisiones "legales" del momento (entrevistas con desmovilizados).

${ }^{29}$ Entrevistas con desmovilizados. 
último -el acatamiento rápido, escueto y maquinal-los miembros de la agrupación clandestina deben hacer suyo un régimen disciplinario hasta creer que constituye la condición misma de su existencia. Y esta es la tarea de inculcación persistente de las FARC, pues solo es posible asegurar la firme obediencia de los súbditos instruyéndolos en la sumisión al estatuto. Los castigos son corrección, atención y ajuste permanentes a la conducta prescrita, al decálogo formativo que se ha interiorizado hasta tener vida propia.

\section{Normas internas de comando}

Pero hay un documento más dirigido a regular la vida militar de los grupos guerrilleros: las Normas internas de comando. Como anuncia el título, el pliego contiene medidas referentes a la marcha de cuarteles y campamentos y a la planeación de misiones especiales. $\mathrm{Su}$ articulado pone especial atención en la vigilancia y protección de las columnas. Al describir las funciones de la guardia surgen centinelas de la más diversa coloración: escuchas, avanzadas, exploratorias y de observación. Todas tienen como tarea cuidar cuarteles y campamentos, y custodiar el descanso, la marcha y el desplazamiento de la tropa. Vigilan la vanguardia y la retaguardia, y atienden la seguridad y escolta de los comandantes. De nuevo se especifican minuciosamente las faltas: pereza y descuido, mentira y negligencia, desobediencia y “aturdimiento". Uno de sus apartados ordena que se debe "pagar el servicio de pie sin sentarse, fumar, comer, beber o conversar" y que el arma debe estar siempre lista - cargada y asegurada- para afrontar cualquier sorpresa. Se califica de delito ocultar información relevante sobre la situación del entorno o el abandono del puesto de vigía y, lo más frecuente en los jóvenes, entregarse al sueño. Se recuerda que "por ningún motivo se permitirá la entrada de civiles a los campamentos". Para su comedimiento se dispondrá de un área especial lejos del albergue de la partida. La atención a la comunidad es sin duda prioritaria, pero jamás debe llegar al extremo de poner en peligro la ubicación del grupo armado.

Las Normas recuerdan a los comandantes que en tiempo de cosecha deben aliviar a los guerrilleros de las obligaciones militares. No se debe descuidar la recolección en las empresas agrícolas del movimiento. Esto sugiere una combinación de roles de sus huestes durante ciertas épocas del año: combatientes en reposo durante la noche y agricultores diligentes durante el día. Ello facilita, además, el camuflaje del personal en las semanas en que el Ejército transita por la región. Cuando atraviesan sus predios, los soldados y sus jefes 
solo ven hombres y mujeres atareados en el cuidado del ganado y en la recolección y almacenamiento del pancoger. Un artículo de las Normas lo establece con claridad:

Los Estados Mayores de Frente y los Comandos, cuando las circunstancias lo exijan y lo permitan, tendrán en cuenta los meses de cosecha y [...] procederán a organizar las labores agrícolas en las que debe participar el personal disponible en su conjunto. [En estos casos se] nombrará el correspondiente jefe de agricultura o de otros trabajos en concreto.

La renuencia a participar en estas tareas es castigada con trabajos no menos agobiantes, como ranchar durante una semana (cocinar para el grupo), cavar trincheras en suelo duro con una pala, o hacer cuarenta o cincuenta metros de chonto (zanjas en los alrededores del campamento para defecar). De allí que un curtido guerrillero indígena del Vaupés recalcara siempre a los recién llegados: "Amigo, no olvide, al cumplidor en las FARC no le pasa nada"30.

\section{EL PARTIDO COMUNISTA CLANDESTINO}

La justicia fariana aparece de nuevo en la reglamentación que rige su agrupación política secreta: el Partido Comunista Clandestino Colombiano fundado en el año 2000. Se llama "comunista" porque desea continuar la tradición radical de los partidos auspiciados por la Unión Soviética, la patria del comunismo. Los comunistas se toman el poder por asalto, no por evolución lenta de los conflictos sociales y políticos alentada por los "asustadizos" partidos socialistas reformistas de Occidente. La creación de este partido en opacidad surgió de la ruptura de las Farc con el viejo Partido Comunista Colombiano que se distanció de la "combinación de todas las formas de lucha". Muchos de sus militantes, los más radicales sobre todo, pasaron a la insurgencia e ingresaron al mundo recóndito del anonimato para actuar como milicianos o combatientes directos. Eran "cuadros", profesionales en la actividad política con alguna familiaridad con la teoría marxista y el trabajo de masas. Muchos de ellos, de clase media con educación universitaria, ascendieron con rapidez en el organigrama del movimiento ${ }^{31}$.

${ }^{30}$ Entrevistas con desmovilizados.

${ }^{31}$ La combinación de las formas de lucha ha sido un tour de force para la izquierda colombiana. El Partido Comunista batalló con la noción leninista por más de medio siglo frenando sus ímpetus sin alcanzar a sofocarla. Lidió con los radicales, partidarios de la violencia, y con los moderados, amigos de la participación electoral. Unos buscaban el poder mediante las armas, otros mediante las urnas, y ambos parecían tener razón y llegar a un acuerdo cuando surgía el agraciado verbo combinar. Para un examen de estas tensiones, ver Giraldo (2015, 91-99). "E1 Partido pregonaba la combinación de todas las formas de lucha de 
El pleno del Estado Mayor de las Farc definió en marzo de 2000 la naturaleza del nuevo partido:

El Partido Comunista Clandestino Colombiano (PCCC) es la expresión más elevada de la unidad ideológica, política y organizativa de la clase obrera y de todos los trabajadores colombianos; es la forma superior de organización $\mathrm{y}$ hace parte de la vanguardia de la lucha revolucionaria insurreccional por el poder político para el pueblo y la construcción del socialismo. Aplica a la realidad colombiana los principios filosóficos y metodológicos del marxismo-leninismo (cursivas del autor).

Dejando de lado la grandilocuencia que alienta el párrafo, la presentación del partido de las tres ces anuncia objetivos nada fáciles de cumplir. En una época en que los socialismos reales -el soviético, los de Europa Central y Oriental (llamados irónicamente "democracias populares"), el chino, el albanés y el yugoeslavo- se desplomaron hasta desaparecer y confundirse con las odiadas sociedades capitalistas de mercado, las FARC insisten en la "construcción del socialismo". Y no solo eso. Desean hacerlo siguiendo "los principios filosóficos y metodológicos del marxismo-leninismo”. Los dirigentes de las FARC persisten, sin rubor, en la añoranza de los nostálgicos militantes de los viejos partidos comunistas de América Latina que "siguen creyendo que lo de 1989 fue apenas un accidente en el camino de la revolución y siguen esperando el retorno del socialismo" en las estepas rusas, en los confines del Río Amarillo y en los países del antiguo imperio austro-húngaro (Delgado, 2007, 156).

No se sabe bien qué entienden los ideólogos de las Farc por estos vocablos unidos por un inofensivo guión. Históricamente el marxismo-leninismo es la doctrina oficial de la Unión Soviética entronizada

masas, pero para la toma del poder aceptaba que la lucha armada sería la forma decisiva" (Delgado, 2007, 288).

Las FARc culpan al Estado colombiano por la elección de la vía armada. En su Programa agrario escribieron: "Nosotros somos revolucionarios que luchamos por un cambio de régimen. Pero queríamos y luchábamos por ese cambio usando la vía menos dolorosa para nuestro pueblo: la vía pacífica, la vía democrática de masas. Esa vía nos fue cerrada violentamente [en 1964] con el pretexto fascista oficial de combatir supuestas "Repúblicas Independientes" y como somos revolucionarios que de una u otra manera jugaremos el papel histórico que nos corresponde, nos tocó buscar la otra vía: la vía revolucionaria armada para la lucha por el poder". El hecho real, sin embargo, es que estaban alzados en armas antes de que entrara el Ejército a la región de Marquetalia, la matriz de las "Repúblicas Independientes" en el municipio de Planadas, Tolima. En sus posteriores trabajos de sabor histórico las FARC, y sus entusiastas, elevaron a mito y gesta heroica su resistencia y salida de Marquetalia. Constituyó su epopeya, su Puente de Boyacá que anidó la fundación de las Fuerzas Armadas Revolucionarias de Colombia en 1966. Como un ejemplo más de las ironías de la historia, una derrota resultó en una victoria. Los "vencidos" se desplazaron a zonas inhóspitas del sur del país, crearon sus comunidades y empezaron -con altibajos- una expansión lenta de medio siglo. 
en el periodo más crudo del estalinismo (1929-1953), que con ligeros cambios se cristalizó y perduró hasta la caída del imperio soviético. ¿Es el legado de Marx unido a la experiencia rusa?, ¿de la embestida revolucionaria, del partido único y de la dictadura del proletariado? Marx enseñó que la sociedad estaba dividida en clases y que su lucha en el periodo del capitalismo desarrollado finalizaba, necesariamente, en la revolución proletaria. Esta abría el camino del socialismo, una sociedad igualitaria, libre, ajena a toda explotación del hombre por el hombre y de amplia participación de sus miembros en la dirección del Estado. Los procesos revolucionarios se frustraron en las naciones de mayor desarrollo, pero surgieron en los países atrasados con alta población campesina donde apenas alumbraba el capitalismo. E1 leninismo fue la respuesta. Ahora la vanguardia del cambio social no era el proletariado sino la alianza de los trabajadores urbanos con el campesinado y otras capas explotadas de la población, grupos marginales, que se daban a la tarea de expropiar a la burguesía, a los propietarios de las empresas productivas de las ciudades y a los señores de la tierra para transformarla en propiedad colectiva. En este escenario el marxismo parecía aportar las ideas, la teoría, y el leninismo la acción, la práctica. Siguiendo las enseñanzas de Marx, una vez afianzado el socialismo surgiría una etapa superior de bonanza: el comunismo. De allí que las FARC y su partido clandestino se apropien de este sustantivo cargado de noble adjetivación que anuncia un futuro de justicia y equidad. El comunismo sería el final de la historia, si esta se definiera como el vivir en un estado permanente de lucha de clases y de conflictos agónicos que desgarran lo mejor de la humanidad.

Esta es la narrativa de las FARC, su esquema histórico. Asumiendo la vanguardia de la evolución social, se han arrogado la conducción en el camino hacia lo inevitable: el socialismo. "Somos revolucionarios y de una u otra manera jugaremos el papel histórico que nos corresponde". Para aligerar este proceso emprendieron "la vía revolucionaria armada", recurso que les "tocó buscar" en razón de que un Estado fascista le cerró las puertas de la vía pacífica al pueblo colombiano ${ }^{32}$. Si las FARC no lo hacen ahora, otra organización representante del progreso y de la conciencia de los tiempos lo hará forzosamente en los días por llegar. No hay posibilidad de que los hombres y mujeres de la alborada del tercer milenio escapen a su destino; su suerte está echada y su porvenir prescrito. Negarse a lo ineludible es persistir en un presente que lleva en las entrañas los elementos de su propia destrucción.

32 Programa agrario de las FARC-EP (cursivas del autor). 
Pero los estrategas de las FARc saben, y lo callan, que mientras llega la sociedad comunista, difundida en su trabajo de masas por los perseverantes activistas del partido de las tres ces, hay una fase de partido único que dura y sacrifica el sudor de varias generaciones. Los cincuenta años de absorbente y despótico socialismo de represión policial cubano son ilustrativos. En la isla caribeña el comunismo es todavía lejanía, un futuro imposible de precisar que apenas se avizora en el horizonte, en esa línea imaginaria que separa el cielo de la tierra y que se aleja a medida que avanzamos. La etapa socialista es la dictadura del proletariado, el férreo poder estatal que se establece para liquidar el viejo orden y asegurar la transición del capitalismo a una sociedad más igualitaria. "La teoría de la dictadura del proletariado, como contenido fundamental del periodo de transición del capitalismo al comunismo, es lo principal en el marxismo-leninismo", apuntaron los autores de un venerado diccionario soviético de mediados del siglo $\mathrm{xx}^{33}$. En este estadio no hay lugar para la sociedad civil; solo se consiente la presencia de la nación controlada por el partido, el organismo de gobierno. Irónicamente, el socialismo se convierte así en un gobierno despótico encargado de imponer la felicidad, el comunismo, la antesala del paraíso donde correrán "a chorro lleno los manantiales de la riqueza colectiva" ${ }^{4}$. En el caso de Colombia serían el Secretariado y el Estado Mayor Central de las FARc los que dirigirían los destinos de la sociedad por un lapso indefinido, jornada que las sucesivas generaciones que recorran la senda hacia el comunismo llevarían a cuestas. Allí no habría ocasión para el grito libertario de aquella criatura de 1984 que conoció el amor: "Cariño, no me interesa la siguiente generación, lo único que me interesa somos nosotros" (Orwell, 2016, 168). En ese camino no hay lugar para la disensión, la prensa libre y la libertad de pensamiento. La actividad sindical, la lucha de partidos o el reclamo de estamentos sociales con intereses particulares serían coartados. Su presencia sería considerada "democracia burguesa", expresión de la sociedad moribunda que se quiere superar. Salvo los delitos corrientes y las querellas civiles entre ciudadanos, la justicia sería fundamentalmente justicia política, afirmación ilimitada del Estado para defender la revolución o a determinados grupos dentro de ella. En la Rusia de los soviets bajo Stalin se expresó en la matanza de bolcheviques durante la segunda mitad del decenio de los treinta (las purgas) y en los procesos amañados para suprimir

${ }_{33}$ Rosental e Iudin $(1961,324)$. Su primera edición en español data de 1946.

${ }^{34}$ Palabras de Marx en su crítica al programa de Gotha (Marx y Engels, 1973, vol. III, 15). 
las posiciones discordantes que terminaron en asesinatos judiciales (Kolakowski, 1983, vol. III, 86-99).

El marxismo-leninismo representa en nuestros días la versión más tosca de la herencia de Marx y Engels. Ha sido repudiado por la propia guilda marxista que lo ha calificado de mecanicista, ideológico, cerrado y burdo. Un insulto a la inteligencia; marxismo vulgar, teoría destinada al pueblo, al vulgo, a la gente sencilla y de escasa educación. Es ciencia e ideología a la vez. Una concepción del mundo que ofrece respuestas a los más diversos desafíos del conocimiento y la acción: la política, la ciencia, la cultura, la economía, la estrategia revolucionaria y el futuro de la humanidad. Un sistema de ideas que legitima las decisiones de los partidos comunistas que están en la oposición o que han alcanzado el poder. Cuando se ha llegado a los tablados del gobierno y de la jefatura de la sociedad, muta en programa oficial al cual debe adherirse toda la población en busca de la etapa final de la realización humana. $\mathrm{O}$ como lo definió el citado diccionario de la URSs, el marxismo-leninismo es la "ciencia relativa $a$ las leyes del desarrollo de la naturaleza y de la sociedad, a la revolución de las masas explotadas, $a$ la victoria del socialismo, $a$ la construcción de la sociedad comunista. [Es la] ideología de la clase obrera y de su partido comunista" (Rosental e Iudin, 1961, 322; cursivas del autor). Y más todavía:

Los partidos comunistas y obreros que se apoyan [...] en la teoría marxistaleninista son la fuerza dirigente y orientadora en la preparación y la realización de la revolución, en la construcción del socialismo y del comunismo. El marxismo-leninismo es una ciencia creadora, que se desarrolla y enriquece constantemente en el proceso del desarrollo y la generalización de la experiencia del movimiento obrero internacional, de la construcción socialista y del desarrollo de la ciencia (ibíd., 324) 35 .

Las FARC han hecho suyo este último llamado: aplican "a la realidad colombiana los principios filosóficos y metodológicos del marxismoleninismo". En este sentido no usan ni forman a sus prosélitos siguiendo lo mejor de las enseñanzas de los autores de El capital y del AntiDühring sino su esclerosis soviética. Trabajan con una codificación ideológica - un sistema de ideas, opiniones y conceptos- que encajan en preceptos simples y en frases lacónicas y radiantes fáciles de recitar en la liturgia fariana pero de clarividencia y profundidad dudosas: "ejército del pueblo", "vanguardia de la lucha revolucionaria”, "gobierno patriótico de liberación nacional”, "lucha contra los ordenamientos fascistas", "superación del régimen oligárquico", "eliminación de la dominación imperialista yanqui”, etc. Su fraseología se traduce, de

35 Ver Schapiro $(1981,27)$. 
esta manera, en una vulgata dirigida a "cultivar" las masas campesinas y congelar el corazón y la mente de sus combatientes adolescentes, muy parecida a los logros formativos de la teología encapsulada del Catecismo de la doctrina cristiana del popular sacerdote salmantino del siglo xvi, el jesuita Gaspar Astete (1845). En esta tarea los eruditos de las FARC parecen olvidar que Marx siempre se preocupó por llevar la excelencia a los sectores populares y llegó a pensar "que sus mejores cosas no eran todavía bastante buenas para los obreros, y que consideraba criminal ofrecerles algo inferior a lo mejor de lo mejor"36.

Con este bagaje teórico no es posible examinar la realidad en sus múltiples caras, y su producto sería una caricatura del país. Su penuria analítica no ayuda a interpretar el mundo y menos aún a cambiarlo para construir una sociedad nueva. De allí que de la intelligentsia de las FARC no haya salido libro alguno que muestre cómo es Colombia y, más allá de eslóganes, cómo se la debería transformar de manera realista. Los panfletos abundan, pero el examen detenido y cuidadoso de la cultura nacional y de su estructura social y económica está todavía por hacerse. Es evidente que si Marx hubiese conocido los acentos marxistas-leninistas propagados por las FARC y sus congéneres habría recalcado: "Todo lo que sé es que yo no soy marxista”, y quizá hubiese añadido: $¡ y$ tampoco leninista! ${ }^{37}$.

Esta estrechez de miras les ha enajenado el apoyo de los "intelectuales demócratas", aun de aquellos de inclinación marxista, aunque a veces consigan una callada condescendencia en los medios docentes de universidades públicas de la capital y de provincia. En general, los intelectuales ven en las FARC una religión bélica de desastrados, muy

${ }^{36}$ Ver la carta de Engels al economista Konrad Schmidt del 5 de agosto de 1890 (Marx y Engels, 1957, 308). El orgullo de su marxismo-leninismo (una filosofía irreligiosa, "científica" y "objetiva") ha servido a algunos combatientes para diferenciarse de sus colegas del ELN (Ejército de Liberación Nacional), muy dados a seguir las orientaciones de antiguos miembros de la Iglesia y de no pocas enseñanzas de la Teología de la Liberación. En sus ratos de ocio suelen corear un despectivo estribillo de tono sexista: "En las FARC el guerrillero es marxistaleninista, en el ELN es marica-seguidista" (entrevistas con desmovilizados).

${ }^{37}$ La conocida sentencia del amigo de Engels surgió de la pobreza y descuido intelectuales de los autodenominados marxistas franceses, entre los cuales se encontraba el dirigente socialista Jules Guesde, muy cercano a Paul Lafargue, cubano de nacimiento y yerno de Marx. En aquellos días, hacia 1880, el suegro le manifestó con desagrado a su yerno: "Ce qu'il y a de certain c'est que moi, je ne suis pas marxiste". La contrariedad fue registrada por Engels en una misiva a Eduard Bernstein del 3 de noviembre de 1882 y reiterada ocho años después en la epístola a Konrad Schmidt. La carta a Bernstein se puede consultar en el útil Marxists Internet Archive. Sobre los desencantos de Marx con sus colegas galos, ver el reflexivo Karl Marx de David McLellan $(1977,510)$ y ese venero de información que es Marxismo y revisionismo del sueco Bo Gustafsson (1975, 304-319), donde examina varios trabajos de Lafargue que el autor encuentra bastante flojos. 
parecida al mensaje del Cristo de Lucas: el que posea caudales debe entregarlo todo a fin de que se abra el camino de la salvación, la felicidad y la abundancia, pues "iqué difícil es que los que tienen riquezas entren en el reino de Dios!" (Lucas 18, 24). Las farc, el "Ejército del Pueblo", solo parecen abrir las puertas de su morada a los necesitados, a las masas populares que todo lo han dado en este mundo y que poco o nada han recibido de él. Cuando se dan algunas libertades electorales llaman en su apoyo a las denostadas clases medias y a la arcana burguesía nacional, pero en general son muy dadas a aseverar que es más fácil que una borrasca de la jungla se detenga en el filo de una navaja, que un terrateniente, banquero o jefe de industria saboree el comunismo, el vergel celestial.

Para conferirle un sabor más hogareño y no depender solo de la experiencia soviética, las FARC añaden un aditamento latinoamericano a su programa marxista-leninista: "el pensamiento revolucionario del Libertador Simón Bolívar”. No es tarea fácil unir estas dos tradiciones, pero las FARC quieren festejar el programa de la vecina República Bolivariana de Venezuela que en silencio tolera sus acciones armadas y socorre a sus efectivos en la frontera. Hacen suyas las críticas de Bolívar a la presencia de Estados Unidos en la América española (su "antiimperialismo"), su prédica por la independencia (la "liberación nacional") y el panamericanismo, la hermandad de los territorios ayer en manos de la corona española. Pero se cuidan de aludir a los intentos dictatoriales del Libertador, a su decreto de "Guerra a muerte" y la sangre que rodó tras él, lo mismo que a su papel nada elegante en la entrega del "Precursor" Francisco de Miranda a las fuerzas españolas. Una vez más, el pasado permanece abierto para los más diversos usos y los más variados silencios ${ }^{38}$.

E1 hecho real es que las FARC no creen en las palabras de un curtido comunista que entregó su vida a las luchas populares:

E1 experimento socialista fracasó, y ese fracaso afecta a su planteamiento teórico [el marxismo-leninismo] y a su práctica social. Los trabajadores colombianos no van a luchar por un pretendido socialismo que, si bien democratizó la propiedad y los servicios públicos, engendró nuevos grupos privilegiados, un nuevo tipo de corrupción del Estado y, sobre todo, perdió la emulación económica con el capitalismo y aplastó las libertades públicas. No pudo producir mejor y más barato que el sistema al cual extinguió, y contuvo la protesta ciudadana ante semejante desequilibrio mediante la represión y el despojo de

${ }^{38}$ A pesar de las inexactitudes y ligerezas del ensayo de Marx "Bolívar y Ponte", aparecido en The New American Cyclopedia de 1858, sus páginas -no exentas de malevolencia- deberían llamar la atención de los ideólogos de las FARC sobre los peligros de una excesiva piedad y entrega a la figura del Libertador. Ver Marx y Engels (1960, 165-184). 
las libertades al grueso de la población. Nadie va a acompañarnos a luchar por ese modelo de "socialismo real" 39 .

E1 Partido Comunista Clandestino se rige por las normas de las FARC emitidas por las conferencias guerrilleras y por el Estatuto, la Carta de la institución. En uno de sus apartes se dice que sus miembros deben ser mayores de quince años, tener buena reputación y honradez reconocida, ejemplo de conducta. En su cuerpo no caben traficantes, alcohólicos, ladrones, consumidores de drogas heroicas, comerciantes inescrupulosos o gente contraria a las costumbres sanas del pueblo. El movimiento tolera el comercio de la droga y saca beneficios económicos de ella, pero jamás debe consumirla. La droga es un mal para alcanzar el bien, así como el Estado produce y distribuye ron y aguardiente con la divisa "el licor es perjudicial para la salud".

Imitando la unidad del organismo biológico, el elemento básico de la organización del partido es la célula, el grupo clandestino que tiene una labor específica. Las células están formadas por tres o cinco miembros, máximo siete, designados por autoridades superiores. Tienen un secretario que coordina las tareas e informa sobre sus actividades a las instancias regionales. Las células se organizan por veredas, barrios, empresas, oficios, profesiones o centros educativos. Constituyen el enlace primario con la comunidad: un colegio, una universidad, los trabajadores de una fábrica, de una mina o de una hacienda. Teóricamente, todo miembro tiene una función concreta y debe estar siempre listo a emprender misiones especiales ordenadas por los niveles superiores. Deben vincularse directamente a las actividades de la comunidad entregando su saber y su apostolado al mejoramiento de sus condiciones de vida y de su conciencia política.

El tipo ideal del integrante del partido de las tres ces es un recurso humano de jornada integral. Un elemento que vive del movimiento y para el movimiento. Pero a veces un miembro de la célula puede ser un estudiante universitario, un maestro de escuela, un tendero, un pequeño comerciante, un chofer de bus o de taxi o un empleado de la cabecera municipal. En este caso se confunde con el perfil del miliciano. Aquí la situación es fluida y se entra y se sale sin mayores traumatismos de un estatus a otro. Si se lo requiere en tareas citadinas se traslada a las milicianas urbanas, y si el mundo de la clandestinidad rural lo reclama se facilita su regreso a las montañas.

Como es de esperar en tareas encubiertas, la disciplina del partido "es firme y seria". Su condición de grupo clandestino exige cuidados

${ }^{39}$ Delgado $(2007,327)$. Delgado militó por más de cuarenta años en las filas del Partido Comunista. 
especiales que garanticen la vida de los militantes y la seguridad de las células. Aquí los estatutos se tornan severos. Repelen la mentira, el fraccionalismo, la calumnia y el incumplimiento de las tareas, así como el robo y la malversación de fondos. Los castigos van desde la advertencia o censura internas hasta la expulsión, pasando por trabajos materiales de utilidad comunitaria, separación del cargo o retiro temporal del partido. Las normas consagran la posibilidad de defensa: "Antes de imponer las medidas disciplinarias, los organismos deben dar a los afectados la oportunidad de hacer descargos". Y cuando las faltas se consideran graves -traición, colaboración con el enemigo, deserción, robo de armas o de fondos del movimiento- el caso se trata “conforme al Estatuto de las FARc", esto es, con la ejecución.

\section{UN PARÉNTESIS WEBERIANO}

A fin de unir los cabos sueltos de nuestra exposición, regresemos al marco general de Weber para visualizar la dinámica de la administración de justicia de las FARC. En las páginas iniciales se describió lo que él llamó "justicia del cadî", una manifestación típico-ideal de justicia irracional ${ }^{40}$.

La sociología del derecho de Weber parte de la idea de que, en circunstancias determinadas, las personas se comportan siguiendo una serie de normas consignadas en constituciones, códigos y reglamentos. Existen reglas formalmente estatuidas, pero también las representaciones que de ellas se hace el hombre común. Entre lo dispuesto y lo acatado hay un margen de subjetividad, una definición particular de la situación. Es el derecho vivido, esto es, como lo ven y experimentan los actores que se rigen por un sistema jurídico. Esta apreciación y sus adecuaciones a la vida real son de especial interés en el análisis concreto de la efectividad del derecho. La distancia entre lo decretado (el precepto) y lo obedecido (la conducta tangible) indica el éxito o el fracaso de un ordenamiento. $O$, para decirlo con términos de Weber, la tarea de la sociología del derecho apunta al estudio de las probabilidades de que la conducta de individuos que

${ }^{40}$ En sentido estricto, la noción "justicia de cadí" no era de Weber. Como él mismo señaló, la tomó del tratado del jurista Richard Schmidt, Manual de derecho civil procesal (1898), pero le dio un giro especial. Lo que en Schmidt indicaba un caso particular, Weber lo convirtió en un concepto general y abstracto de justicia irracional-material. Lo mismo sucedió con la noción de carisma que tomó del Derecho eclesiástico (1892) del romanista e historiador de la Iglesia Rudolph Sohm, pero que en su "sistema" lo elevó a vocablo con carga analítica para ilustrar las manifestaciones de la "gracia" -lo especial, particular y único- de personas, grupos e instituciones en los más diversos contextos sociales y culturales. Ver Haley (1980, 185-186 y 195-197). 
actúan en comunidad se vea orientada por un orden que consideran válido $^{41}$. Para que el mandato se ejecute con alguna regularidad deben existir medios coactivos que velen por la certeza de la sujeción. En la sociedad mayor son los tribunales, las penitenciarías, el Ejército y la Policía; en las FARC el control directo, total y absorbente de la vida del insurgente, y la sugestión de la comunidad estimulada por la presencia de los milicianos, por la catequesis de los apóstoles del partido de las tres ces y por el desfile periódico de guerrilleros por las veredas. Estos agentes, en íntima reciprocidad, fustigan la mente de los moradores, les recuerdan las disposiciones y les encarecen su cumplimiento para la "buena marcha" del vecindario bajo su influencia.

Una vez establecidos estos principios, Weber pasa a construir los tipos ideales del derecho: el racional y el irracional. Weber entiende aquí por racional no la persona o institución que piensa y juzga, que usa la razón, sino la acción mediante la cual se sistematizan los elementos constitutivos de una dimensión de la cultura. El proceso como tal recibe el nombre de racionalización. Los teólogos, por ejemplo, se encargan de articular los fragmentos dispersos de las religiones para fundar una doctrina armónica manejable para los creyentes y para los funcionarios sagrados (sacerdotes) que administran la Iglesia. Los partidos políticos organizan mediante secretarías y oficinas centrales y regionales la ideología de una facción, y la lucha por el poder ayer en manos del capricho, voluntad y empeño de los líderes carismáticos. En la esfera jurídica es la superación de la legislación especial, y del dictamen intuitivo, por un sistema legal al que se puedan remitir los casos particulares. Lo contrario de racional es la existencia ad infinitum de experiencias inorgánicas carentes de una imagen indivisa y unitaria. A falta de una norma común y abstracta el juez se ve obligado a abordar caso por caso, situación que lo lleva - por descuido, error o decisión personal- a juzgar el mismo hecho de manera diferente o, aún más, dos hechos distintos y contrapuestos del mismo modo ${ }^{42}$. A esto Weber lo llamó acción irracional, "caos" jurídico, algo que descansa en el albedrío de las magistraturas por falta de un marco general que regule y oriente sus decisiones. Aquí irracional no alude a abandono de la razón sino a la ausencia de principios y preceptos que enlacen y den sentido a la afluencia de casos que van y vienen. En

${ }^{41}$ Weber $(2014,701)$. El derecho solo regula al individuo en sociedad, en permanente comunicación e intercambio con los demás. E1 hombre aislado es anomalía, no existe para la sociología del derecho. La soledad es mala compañía para las ciencias sociales.

${ }^{42} \mathrm{La}$ reflexión es de Bobbio, que conocía bien la obra de Weber (Bobbio, 2004, 207). 
este estado de cosas la posibilidad de calcular, de prever los resultados de una decisión judicial, es prácticamente nula y los implicados en los procesos estarán siempre en vilo. Cualquier cosa puede suceder.

Puesto que la realidad no es tan simple, Weber sumó dos variables más a su contraposición típico-ideal. Introdujo los conceptos material y formal para hablar de derecho racional-material y derecho racional-formal, lo mismo que de derecho irracional-material y derecho irracional-formal. Era una contraposición que le servía para distinguir los acentos del derecho en acción, esto es, los procesos y los criterios de decisión adoptados por los operadores jurídicos. Con ello quería evitar tosquedades y sugerir fluidez en un campo complejo que orienta, o pretende orientar, la conducta de los miembros que actúan en comunidad bajo el abrigo de unas normas que suponen legítimas. Por derecho formal entendía el sistema jurídico que se nutre del acervo de normas sistematizadas generación tras generación. Por derecho material, que otras tradiciones jurídicas llaman sustantivo, entendía la actividad jurídica que se rige por demandas éticas, sentimentales, políticas o religiosas y no por el acopio doctrinal atesorado y sistematizado a lo largo de los años. La sociología del derecho pone especial cuidado en la lógica que asiste al derecho material porque es el que tiene en cuenta la situación del evasor de la ley, sus intenciones y las condiciones de su existencia. En el primer caso -el formal- el juez aplica la ley sin vacilaciones, en el segundo -el material- medita la norma estatuida, la interpreta con amplitud, consulta su conciencia y enseguida emite el dictamen que considera más equitativo. Y si bien esta era su distinción básica, a veces Weber se inclinaba por otra perspectiva muy corriente en nuestros días, la que identifica el derecho formal con el procedimiento, con el modo de aplicar las normas. Algo parecido ocurría con el derecho material, expresión que también empleaba para aludir al contenido del derecho, a la disposición concreta que señala qué conducta se debe seguir en una situación determinada. Un ligero esquema de sus elementos constitutivos muestra la trabazón -algo compleja pero sensible a la diversidad de casos que presenta la realidad- de su marco de referencia ${ }^{43}$.

${ }^{43}$ El esquema jurídico de Weber, que se resume aquí de manera bastante apretada, se encuentra en Weber (2014, 737-741 y 1167-1170). Para una discusión más amplia ver la notable monografía de la española M. J. Fariñas (1989, 213230) y la introducción de Max Rheinstein a su traducción inglesa, con Edward Shils, de Max Weber on law in Economy and Society (1954, xxv-1xxi). Ambos textos, indulgentes con el lector no iniciado en la tortuosa prosa colmada de tecnicismos y opacidades del sociólogo alemán, presentan con claridad los problemas centrales de su sociología del derecho. Dos inteligentes libros generales son igualmente instructivos: Bendix (1970) y Freund (1967). El ensayo del argentino Guillermo 
I. Derecho irracional: ausencia de reglas generales. Derecho empírico, casuístico.

1. Material: el juez y el legislador basan su labor en valores emocionales al margen de toda referencia a una norma. Se asemeja a la justicia dictada por el déspota. Es la justicia del cadí que, sentado en el mercado o en un cuartucho, emite su fallo según su arbitrio. Es el imperio de la reacción ante los casos individuales. Este es, por supuesto, un caso extremo. En realidad, el cadí respeta las creencias religiosas y las adhesiones políticas del pueblo.

2. Formal: el juez y el legislador se dejan llevar por medios que escapan al control de la razón (ordalías, oráculos, buena suerte, sabiduría del pueblo, etc.).

II. Derecho racional: guiado por reglas generales derivadas de un pensamiento jurídico visto como un sistema completo y acabado.

1. Material: el juez y el legislador se guían por un libro sagrado (el $\mathrm{Co}^{-}$ rán), por la voluntad política de un conquistador o por una ideología. 2. Formal: la ley y los juicios siguen reglas generales tomadas de conceptos abstractos creados por el pensamiento jurídico. Derecho "puro".

En la mente de Weber no había, por lo demás, derecho "malo" o "bueno". Solo derecho, conjunto de reglas que presiden la conducta de los individuos en sociedad. El derecho racional no es mejor que el irracional o este último más "humano" que el racional. La exaltación o rechazo de uno u otro pertenece al reino de la opinión y del punto de vista, a los juicios de valor que el sociólogo alemán definía como la evaluación de un fenómeno a partir de nuestro razonamiento de lo deseable y nuestra apreciación de lo correcto (Weber, 2010, 65).

La combinación derecho irracional-material es la de mayor interés para examinar la justicia de las FArc. Aquí reaparece la justicia cadí y sus afines: ordalías, juicios de dios, justicia popular. Todas ellas son antijurídicas en el sentido de que no se nutren de reglas generales que han soportado severos procesos intelectuales de generalización y sistematización. No hay abogados ni tratadistas, sino operadores jurídicos impulsados por valores y creencias últimas, y acusados en espera de ecuanimidad o una actitud benigna de los representantes de la ley. Cuanto más acentuado es el carácter religioso, político o sentimental de un prefecto, mayores serán también las posibilidades del dictamen arbitrario. Lo opuesto al derecho irracional-material es

Munné (2006, 69-99) trata en pocas páginas problemas de interés para el análisis de procedimientos informales. 
el derecho racional-formal, el derecho "puro", donde lo jurídico material y lo jurídico procesal se unen para atender las querellas. Es danza acompasada entre la noción abstracta y el hecho concreto, derecho sin lagunas que todo lo resuelve y a todo da respuestas lógicas extraídas de una rica cantera legal acumulada y refinada por los eruditos del pasado lejano o reciente.

La sinopsis anterior es, por supuesto, una caricatura que extrema los comportamientos jurídicos. Esos derechos jamás se encuentran en su estado puro. Su enunciado es solo una construcción teórica y una guía para determinar el grado de racionalidad o irracionalidad y de formalidad o materialidad de un sistema jurídico del pasado o del presente. El marco de referencia de Weber es sinuoso y evasivo. Parte de postulados generales, los tipos ideales, para orientar la observación de los hechos, pero la realidad presenta tantos matices que el análisis de los casos termina en una mezcla desconcertante de elementos de uno y otro tipo. En sentido estricto la justicia del cadí no es arbitraria. Sigue los llamados religiosos y morales del Corán, observa los usos y atiende los precedentes establecidos poniendo especial cuidado en las decisiones de los colegas. Cuando se juzga un caso que no parece tener ejemplos en el pasado, se vale del razonamiento por analogía en vez de romper con la tradición. Se esfuerza por las semejanzas, para no desgarrar las viejas prácticas extendidas. Sabe que todos deben ser juzgados de manera semejante o al menos en condiciones parecidas. Con ello protege los intereses de los que reclaman justicia y el honor del cadí, con gran ascendencia en la comunidad. La arbitrariedad es estigma en el ejercicio del cargo (Bobbio, 2004, 208). Algo semejante ocurre con el derecho racional-formal. Esta jurisprudencia no se desembaraza del todo de cataduras irracionales. El juramento, tomar a Dios como testigo, está entronizado en sus prácticas. Igual sucede con los jurados, una institución que "no sabe derecho" y supuestamente representa el "alma" de la comunidad. No se deben dejar de lado, por lo demás, las ceremonias religiosas o laicas que acompañan a ciertos actos. $\mathrm{E} 1$ mismo Weber las llamó casos extremos de formalismo jurídico y las enumeró: "Por ejemplo, cuando se exige que una determinada palabra sea pronunciada, que se estampe una firma, o que se ejecute una acción cuyo significado simbólico ha sido establecido definitivamente" por la sociedad o por los mismos juristas (Weber, $2014,740)^{44}$.

${ }^{44}$ Estos ritualismos - cantos, himnos, misas, aplausos, palomas al aire, etc.-, muy
corrientes en los acuerdos y tratados de paz, son prácticas irracionales introducidas
en la impávida sequedad de los códigos. En muchos aspectos son sobrevivencias 


\title{
ELEMENTOS IRRACIONALES DE LA JUSTICIA POPULAR
}

Weber consideró la justicia popular como una de las reacciones más efectivas contra el derecho racional-formal. Tendía a definirla como la reacción de los sectores económicamente débiles ante los intentos de implantar un derecho universal sin atender a los problemas particulares de las masas. A su juicio, a esta justicia la animaba un ethos, la firme creencia de que el pueblo no reclama ni necesita paridad ante la ley, sino equidad en un mundo marcado por profundas desigualdades sociales. El derecho, la misma regla para medir personas diferentes, abandona para los desposeídos la idea de ecuanimidad propagando la igualdad de lo desigual. Aquello de lo que se burlaba Anatole France cuando abordó una de las contribuciones más festejadas de la Revolución Francesa: "la majestuosa igualdad de las leyes que prohíben, tanto al rico como al pobre, acostarse bajo los puentes, mendigar en las calles y robar un trozo de pan" (France, 1955, 85-86). En pocas palabras, los pobres no necesitan semejanza ante la ley, sino preceptos materiales equitativos que vigilen sus intereses ante la rapacidad de las clases altas. Las llamadas "reivindicaciones" de la clase trabajadora. Esto frena la imperiosa racionalidad formal, que pretende legislar para toda la sociedad sin atender a las diferencias entre sus miembros. E1 resultado es un sistema jurídico fraccionado que al cubrir las diversas demandas de las partes termina sacrificando el todo. Weber escribió:

\begin{abstract}
Una igualdad formal ante la ley y una distribución y administración racionalmente calculables, tal como las exigen los intereses burgueses, no sirven a las masas desposeídas. Desde las perspectivas de éstas, es natural que la justicia y la administración de bienes sirvan para subsanar las carencias de sus oportunidades económicas y sociales de vida, respecto de las clases poseedoras. Pero la justicia y la administración solo pueden desempeñar ese papel si asumen en gran medida un carácter informal, es decir, un carácter sustancialmente "ético" (o de cadí). Todo tipo de justicia popular, así como todo género de influencia de la llamada opinión pública sobre la administración, traban el desarrollo racional de la justicia y de la administración con una fuerza semejante a la de los manejos astrológicos de un gobernante absoluto. En este nivel, es decir, en las condiciones de una democracia de masas, la opinión pública se reduce a un comportamiento comunal surgido de "sentimientos" irracionales. Por lo general, la difunden o determinan los dirigentes de partido y la prensa $(2014,1171)^{45}$.
\end{abstract}

de costumbres antiguas como la de sangrar la palma de la mano y unirla con otra para cerrar un pacto, sellar una hermandad o fortalecer un vínculo de amistad.

${ }^{45}$ En aras de la claridad de este significativo y encrespado texto de Weber, citamos la traducción más sosegada del argentino Rufino Arar aparecida en Weber (1978, 61-62). La justicia por aclamación, la asamblea que juzga en pleno, es un proceso irracional en el corazón de la legislación fariana. Trastorna de continuo los intentos formales de sus estatutos. Muchas veces los comandantes deben recordar a las bases que no han de dejarse llevar por el sentimiento hasta llegar a sacrificar la regla asentada en los reglamentos. 
Este reclamo no ha terminado. En los días de Weber era la lucha por las dispensas de la clase obrera, olvidadas por el avance de la inanimada legislación racional-formal que todo lo quería medir y legislar con un solo trazo. En la época actual son las legislaciones de clase, de responsabilidad y seguridad sociales de los trabajadores, o el respeto por las normas de grupos con características especiales como las comunidades indígenas, los afrodescendientes o las instituciones con prerrogativas para sancionar a sus miembros (Iglesia, Ejército, Policía). Este es el terreno abonado del pluralismo jurídico, de la fuerza antiformal -irracional, en la terminología de Weber- que cercena el ideal de un derecho único, absoluto y universal ${ }^{46}$.

En la actualidad la idea de justicia popular se ha enriquecido con nuevas manifestaciones. Ya no alude solo a la defensa de los intereses de clase sino a la afirmación del pueblo como juez y corte. De nuevo la voz pueblo involucra aquí muchas cosas. Son las clases económicamente débiles de un país o un grupo más reducido - un barrio, una vereda, una comunidad indígena, una hermandad racial- que se reúnen para juzgar, con normas propias, los delitos cometidos en su interior. Su espectro es muy amplio y las modalidades de administración de justicia igualmente dilatadas. En un extremo se encuentra el populacho enfurecido que se toma las calles para ajusticiar a un violador consuetudinario; en el otro, el homicida que cae en manos de la comunidad, y esta le entabla juicio siguiendo unos pasos que incluyen defensa y argumento del implicado. El primero resulta en condena inmediata, en una réplica de la vieja práctica del político, plantador y juez de paz de Virginia, Charles Lynch, que a finales del siglo XviII, cuando se afirmaba la independencia norteamericana, erigió una corte irregular para castigar a los adeptos a Inglaterra. Sin mayores miramientos los hacía colgar, los linchaba para sempiterna memoria de su apellido. En el segundo caso el delincuente es juzgado y castigado siguiendo los usos y costumbres de la comunidad (azotes, trabajos comunales, pago de daños a terceros, etc.) o, como último recurso y siempre atendiendo a lo establecido por la tradición, ajusticiado.

\footnotetext{
${ }^{46}$ Con consecuencias negativas para el mando del Estado central. El pluralismo da libertad y respiro a quien lo ejerce, pero limita la actividad y la gestión del Estado. Al trasladarse a la política, es la existencia de grupos reconocidos que limitan la capacidad decisoria de los gobiernos. Esto da lugar a la policracia, el concepto acuñado por Carl Schmitt para aludir al poder de "un conjunto de titulares jurídicamente autónomos [...] en cuya independencia encuentra una limitación la voluntad política [del Estado]" (Schmitt, 1983, 126). El esclarecedor Bobbio también reflexionó sobre el asunto en el primer ensayo de El tiempo de los derechos (1991, 27-35). Ver también Migdal (2011, 75-77).
} 
Estas manifestaciones de justicia popular, diferentes a la que estudió Weber aunque tengan afinidades, usurpan funciones del Estado. A menudo las comunidades administran justicia fuera de los tribunales oficiales porque el Estado es lento o incapaz de proporcionarla, porque sus medidas judiciales carecen de legitimidad entre grupos sociales con culturas diferentes pues la imparten entidades por fuera de la ley. Estos casos son manifestaciones de pluralismo jurídico, de leyes paralelas a las del sistema estatal. Sociológicamente hablando, hay pluralismo jurídico cuando grupos enteros y de algún peso demográfico siguen normas propias y específicas diferentes de las emitidas por el Estado. Este énfasis lo distingue de la dogmática jurídica, que solo acepta el pluralismo cuando el Estado consiente o tolera en su territorio la existencia de un derecho diferente al suyo. Así, las entidades oficiales no reconocen como derecho, como fuente de justicia, las prácticas judiciales de guerrillas, paramilitares, narcotraficantes o empresas criminales, pero sí las de algunas comunidades indígenas, aunque no todas sus manifestaciones. Rechazan, por ejemplo, las ejecuciones, la ablación -la mutilación genital femenina- o los azotes, a los que se considera cercanos a la tortura ${ }^{47}$.

${ }^{47}$ Hay mucho más que decir, por supuesto, sobre la justicia popular de nuestros días. No siempre es expresión de los indígenas, de grupos de izquierda, organizaciones por fuera de la ley o sectores populares, aunque es típica de estos últimos. Sus relaciones con el derecho estatal son, en general, de tensión y conflicto. Cuando actúan como jueces de paz, las comunidades reciben alabanzas de organismos del Estado; cuando ajustician por cuenta propia, son estigmatizadas. Las autoridades esperan que todo delincuente capturado se lleve a la comisaría, pero es común que al atracador que allí pernoctó a poco se lo vea rondando por el barrio que desplumaba en compañía de sus amigos. Las cárceles del Estado están abarrotadas y no hay espacio para el delincuente de centavo, que apenas vive de lo hurtado, pero empobrece aún más al necesitado al robarle electrodomésticos y enseres hogareños reunidos con el sudor de varios años de trabajo. Además, y como se mencionó en páginas anteriores, la justicia oficial ordinaria impone costos y trámites agónicos: papeleos, citas, idas y venidas que agotan la paciencia de los afectados hasta que la demora se traduce en exaltación y furia, en justicia por mano propia. Se piensa que solo un $7 \%$ de las querellas civiles y penales llega a último término. Las demás se quedan en los apolillados anaqueles de los juzgados para incomodidad de los funcionarios de turno.

A lo anterior se suman las deficiencias del Estado: escasez de personal, bajo cubrimiento de la seguridad urbana, escasa presencia en regiones enteras de la geografía nacional y -lo más significativo para los afectados- solución insatisfactoria de los casos. El Estado se queja de la expropiación y el despojo de sus funciones judiciales, pero cuando las ejerce responde con irritante precariedad. Frente a sus flaquezas surgen con furor las prácticas informales de la sociedad civil, "ciudadanos rabiosos", que terminan socavando el pretendido monopolio del Estado en asuntos de justicia racional-formal. Para mayores reflexiones sobre el asunto ver Merry (2004, 39-74) y Ardila (s. f. y 2002, 45-97). Sobre la noción de grupos que actúan bajo la impronta de la ira en la sociedad moderna, ver Vargas L1. (2016). 
Cuando un grupo se organiza y se distancia del Estado tiende, consciente $\mathrm{o}$ inconscientemente, a establecer una serie de normas para salvaguardar su coherencia y regir sus relaciones con el exterior. Las primeras afinan su cohesión interna y las segundas su naturaleza, su "personalidad". Las FARC y sus códigos son un ejemplo de las pautas de mando y obediencia de un movimiento que se organiza para el ejercicio de la violencia y la toma del poder por la fuerza. El ideal que lo impulsa es la revolución y a este valor entrega su destino. Mientras lucha, quiere discutirle al Estado no solo el nervio de la autoridad regional, sino también el ejercicio absoluto de la esfera jurídica en esos territorios. Legisla para sus organismos armados y decreta para las comunidades bajo su influencia. Pero cuando alcance los objetivos y se mude de las montañas al palacio de gobierno, las cosas serán sin duda distintas. En ese momento habrá un solo derecho para toda la sociedad regida por el Estado socialista. Se constreñirán las normas autónomas que compitan con la legislación central. Entonces habrá un ejercicio cabal y completo del poder por el cual se hizo el alzamiento. En la oposición, el pluralismo es funcional, así como los reclamos de participación, pero al ascender a la administración de la nación se subraya la cohesión y el orden. Un Estado totalitario no soporta la existencia de legislaciones independientes que frenen o distorsionen la construcción de la nueva sociedad que, como ya se dijo, estará bajo la dictadura del proletariado por un tiempo indeterminado. En la oposición se clama por la democracia y cuando se accede a la primera magistratura se impone la autocracia.

\section{CONSIDERACIONES FINALES}

Las páginas anteriores fijaron la atención en la actividad jurídica de las FARC en lo que respecta a sus militantes y a la administración de las comunidades bajo su mando. Pero un modo de ver también es un modo de ocultar. El investigador es selectivo, y al subrayar un aspecto de su tema de estudio descuida los demás hasta dejarlos en un claroscuro que no permite ver su papel en el conjunto. La campana de un campo de concentración se usa para anunciar el descanso y la finalización de las agotadoras tareas diarias, pero también para reunir a los judíos de un patio que se llevarán al crematorio. Quien reduzca la mirada al primer uso y olvide el segundo dejará mucho que desear. Nada o poco se ha hablado aquí de los delitos de las fArc contra la sociedad mayor, especialmente de los de lesa humanidad: masacres, crímenes de guerra, toma de rehenes, tortura, ejecuciones extrajudiciales, desaparición forzada, acceso carnal violento y reclutamiento 
de menores. Sus dirigentes no los perciben como tales sino como acciones "justas" de defensa en un clima de confrontación.

Hay además un ejemplo que se olvida o se deja en segundo plano. Durante años las FARC han sembrado regiones enteras de minas antipersona para defender sus asentamientos. Un cordón de seguridad que advierte la presencia del Ejército y demás grupos adversos. Pero cuando abandonan las regiones y se trasladan a otros escenarios de confrontación, dejan a sus moradores y a los hijos de sus hijos una herencia de latrocinio y muerte. En las familias pobres la existencia de un mutilado provoca más problemas que un muerto. Las FARC son hábiles para enterrar artefactos, pero poco dadas a desactivarlos cuando abandonan una zona. Dejan sus siniestras guacas para terror de hombres, mujeres y niños de la comarca. Aun sus propios efectivos han sido víctimas de los explosivos que han sembrado en las inmediaciones de los campamentos. Muchos guerrilleros ostentan cicatrices en su cuerpo o han perdido ojos, piernas y brazos por olvido, descuido o huida desesperada. Jóvenes que quieren desertar no lo hacen por desconocimiento del territorio y por temor a pisar una mina en el escape. Lo que sirve para detener al enemigo también sirve para retener al combatiente ${ }^{48}$. No hay que olvidar que cuatro años después de la guerra del Vietnam, finalizada en 1975, los habitantes de la nación asiática seguían escuchando detonaciones cuando los niños jugaban en patios escolares, cuando las mujeres con el agua hasta la cintura trabajaban en arrozales o una partida de búfalos inocentes vagaba por sendas minadas y ya olvidadas. Sin contar los valiosos semovientes de una población empobrecida por la guerra, cerca de cuatro mil personas del país asiático había muerto por acción de estas trampas antes de 1980. Y las víctimas aumentarían en los años siguientes ${ }^{49}$. La mina, apuntó una campesina,

${ }^{48}$ Entrevistas con desmovilizados.

49 García Márquez (1999, vol. Iv, 245). "En Colombia hay 11.458 víctimas por minas y únicamente en la isla de San Andrés no hay presencia de estos artefactos", informó la revista Semana (2016a). Entre ellos hay niños, niñas, adolescentes, indígenas, afrodescendientes, guerrilleros, paramilitares y miembros de la Policía y del Ejército. Desactivar una mina cuesta entre tres y cinco millones de pesos. Los expertos calculan que desminar el país en los próximos diez años exigiría invertir 327 millones de dólares (Semana, 2016b). Las minas antipersona se convirtieron en una efectiva estrategia militar de las FARC para contener el avance paramilitar en sus territorios y para sofocar las incursiones del Ejército en las regiones abandonadas del país a principios del siglo xxi. Ver el informe del Grupo de Memoria Histórica (2013, 93) y el sugerente libro comparativo de Misha Glenny $(2009,357)$. Un caso ilustrativo de las dificultades para desminar grandes zonas es la experiencia danesa de 1945. Después de la guerra, más de dos mil prisioneros alemanes fueron obligados a desenterrar cerca de millón y medio de minas sembradas por los nazis en las playas occidentales de Dinamarca 
es un soldado perfecto: no pide sueldo, no duerme, no descansa. Trabaja las veinticuatro horas del día, toda la semana, todo el mes, todo el año. Se mimetiza y -llueva, tiemble o relampaguee- nada le pasa. Puede durar en su nicho quince o veinte años y siempre está lista para mostrar su furia destructiva a quien se le pare encima ${ }^{50}$.

Cuando la guerrilla llega a una región, limpia el espacio de justicia estatal, "reaccionaria" y "burguesa". Expulsa a los jueces, a la Policía (la salvaguarda de las sentencias) y entroniza su novedad, la "justicia revolucionaria”. Usurpa las funciones del Estado o llena el vacío donde este apenas hacía presencia. Es allí donde surge el campo abonado para la violación de los derechos humanos. El control se traduce en coacción directa, en intimidación y agresión continuas, con grave afectación de las libertades individuales. Los movimientos de los moradores, sus salidas y entradas, son vigilados y la disensión muta en silencio. Esto abre el campo movedizo del secuestro, la tortura, la desaparición forzada, el reclutamiento de menores, las ejecuciones extrajudiciales y la violencia sexual. Es voluntad revolucionaria aupada por la subyugación y la vendetta.

Con sus prácticas, las FARC pauperizan aún más a las poblaciones vecinas. Su acción lacera al pueblo en nombre del pueblo. Incursionan en un poblado, toman rehenes y maltratan miembros de la población civil ajenos al conflicto armado. Expulsan familias enteras que abandonan sus propiedades, malvenden sus haberes y pierden las fuentes de sustento para entregarse a la mendicidad vergonzante en los centros urbanos. Han abandonado la guerra civilizada, el viejo precepto compartido por rebeldes y revolucionarios del pasado, de que la guerra es entre combatientes y no entre estos y ciudadanos desarmados. La ejecución de jóvenes, cuyos nombres se pierden en la frágil memoria de los compañeros, imita las vejaciones de los actores armados contra los cuales dicen luchar. Su uso indiscriminado de cilindros bomba -recipientes de gas llenos de explosivos y metralla, cuya dirección y cuyo blanco no se pueden controlar después de ser lanzados- destruye calles, casas, escuelas y servicios públicos de corregimientos abandonados y asoladas cabeceras municipales. Sus ataques a oleoductos y camiones cisterna arruinan la pesca en ríos y quebradas, devastan la flora y la fauna, y siegan el suministro de agua a los hogares de los agricultores. Derriban torres de conducción eléctrica oscureciendo los poblados, y para prevenir el desembarco de los ejércitos aliados. La mitad de los prisioneros murió o cayó herida en las difíciles labores de desactivación. Una remembranza de esa brutal experiencia se encuentra en la película de Martin Zandvliet, Bajo la arena (2015), que anuncia las angustias que habrán de soportar los campesinos colombianos que transiten por su heredad en los duros años del posconflicto.

${ }_{50}$ Resumen del testimonio recogido por los investigadores del Grupo de $\mathrm{Me}$ moria Histórica (2013, 95-96). 
cortan puentes, caminos y carreteras, aislando las poblaciones de los centros comerciales. Todo ello en busca de una sociedad de armonía y felicidad. Con estos daños y perjuicios se alejan del objetivo de su Programa agrario: "Luchamos por el establecimiento de un régimen político democrático que garantice la paz con justicia social, el respeto de los Derechos Humanos y un desarrollo económico con bienestar para todos quienes vivimos en Colombia" 51 .

Por último, nada se ha dicho sobre los enfrentamientos de las FARC con otros grupos alzados en armas, como el EPL (Ejército Popular de Liberación) o el ELN, donde han muerto decenas de combatientes. Son luchas entre guerrillas, entre compañeros anti statu quo; revolucionarios devorándose entre sí por los territorios, por liderazgos regionales, por tensiones ideológicas o por ansias de robustecer la tropa con efectivos de los otros. En esas riñas los más sacrificados han sido los líderes locales de una u otra organización, siempre más visibles y fáciles de hostigar que los mandos medios y altos de las cuadrillas confinadas en las montañas. Y no solo eso. Las FARC han sacrificado dirigentes comunistas que no siguen sus combinaciones de lucha. "Eliminan a ciudadanos elegidos por el voto popular, incluidos los de izquierda”, señaló Delgado en su autobiografía. Los invitaban a las montañas a discutir sus tesis políticas y allí "estaban los soplones que te ven llegar, te fichan y te venden al enemigo. Esa es la más extendida y barata forma que he conocido de señalamiento de la gente por los mismos combatientes". Y añadió: "Estoy seguro de que una buena parte de las tergiversaciones que andan en boca de la gente acerca de algunos dirigentes del Partido [Comunista] ha salido de las filas guerrilleras" 52 .

${ }^{51}$ Se espera que el socialismo, una sociedad amable y justa que educa y forma para la paz, sea el germen perdurable de comprensión y tolerancia entre pueblos de cultura, idioma, confesión religiosa y fenotipo diferentes. La caída del régimen yugoeslavo mostró, sin embargo, que no era así. Una vez se disolvió la federación de los eslavos del sur, en 1990, surgieron con desconcertante furor el nacionalismo y la lucha étnica, política y genocida entre sus seis repúblicas (Serbia, Eslovenia, Croacia, Bosnia-Herzegovina, Macedonia y Montenegro). En estas tierras balcánicas -escribió el historiador Eric Hobsbawm- "la fuerza mayor de una dictadura comunista no impidió que las comunidades bosnias se degollaran mutuamente" (Hobsbawm, 1998, 263).

${ }_{52}$ Delgado (2007, 240-241, 287, 299-300). Las relaciones de las FARc con el Partido Comunista fueron siempre de simpatía y ahogo. El Partido les proporcionaba cuadros y las FARC lo criticaban por su inercia y blandura. En los años sesenta y setenta -relata Delgado- "todo el que entraba a la guerrilla automáticamente se convertía en miembro del Partido". En esa época su Comité Central llegó a tener más de diez miembros que eran combatientes activos. Manuel Marulanda “Tirofijo", por ejemplo, ingresó al Comité Central en 1962, el mismo año que Delgado, pero jamás asistió a una reunión y nunca se supo que hubiese renunciado a la emblemática curul (ibíd., 283). Delgado y Marulanda eran de la 
En este ensayo no se examinó ninguno de estos problemas. Están latentes, solo como contexto de las prácticas judiciales de las FARC. Su ausencia, sin embargo, no es grave. Han sido tema de reiterados trabajos, informes y memorias auspiciados por el Estado, universidades, comisiones internacionales u organismos que siguen las orientaciones del derecho internacional humanitario. Y aún más, en el futuro serán tema obligado de la Comisión de la Verdad acordada en las negociaciones de La Habana, que fijará su atención en la investigación y judicialización de los crímenes de lesa humanidad, vejámenes que por su naturaleza y sus características ultrajan y deshonran a toda la humanidad.

\section{REFERENCIAS BIBLIOGRÁFICAS}

\section{Libros, ensayos y artículos}

1. Aguilera P., M. Contrapoder y justicia guerrillera: fragmentación política $y$ orden insurgente en Colombia, 1952-2003, Bogotá, IEPRI, 2014.

2. Alighieri, D. Comedia: Infierno, trad. de Ángel Crespo, Barcelona, Seix Barral, 1982.

3. Álvarez P., C. y L. Suárez F. La España musulmana y los inicios de los reinos cristianos, 711-1157, Madrid, Gredos, 1991.

4. Ardila A., E. "Justicia comunitaria y el nuevo mapa de las justicias", Criterio Jurídico 2, 2002, pp. 45-97.

5. Ardila A., E. "Justicia comunitaria y sociedad nacional", s. f., [www. justiciacomunitaria.unal.edu.co].

6. Astete, G. Catecismo de la doctrina cristiana, explicado por S. J. García Mazo, Bogotá, Imprenta de José A. Cualla, 1845.

7. Ávila, A. "Así administran justicia las Farc en sus territorios", Semana, Bogotá, 20 de abril de 2016.

8. Ávila, A. y J. D. Castro L. Los retos en convivencia, administración de justicia y seguridad rural en el posconflicto, Bogotá, Fundación Friedrich Ebert, 2015.

9. Ávila, A. y L. Valencia A. Los retos del postconflicto: justicia, seguridad $y$ mercados ilegales, Bogotá, Ediciones B, 2016.

10. Battuta, I. A través del Islam, Madrid, Editora Nacional, 1981.

11. Bendix, R. Max Weber, Buenos Aires, Amorrortu, 1970.

12. Berman, Harold J. La formación de la tradición jurídica en Occidente, México DF, Fondo de Cultura Económica, 1996.

13. Biblia de Jerusalén, "Evangelio según San Lucas", Bilbao, Desclée de Brouwer y Alianza, 1994.

14. Bloch, J. Los gitanos, Buenos Aires, Eudeba, 1962.

misma edad; ambos nacieron en 1930, el primero en Popayán y el segundo en Génova, Quindío. A lo largo de los años conservaron la tenue amistad que concede la lejanía: uno en la ciudad, el otro en las montañas. Sus pocos encuentros eran presididos por el familiar "camarada" o por su traducción latinoamericana, "compañero", vocablos de la izquierda que anuncian afinidad y compromiso con las tareas de la revolución, por dispares que sean los medios para alcanzarla. 
15. Bobbio, N. Norberto Bobbio: el filósofo y la politica, antología de J. Fernández Santillán, México DF, Fondo de Cultura Económica, 2004.

16. Bobbio, N. El tiempo de los derechos, Madrid, Sistema, 1991.

17. Brundage, J. A. La ley, el sexo y la sociedad cristiana en la Europa medieval, México DF, Fondo de Cultura Económica, 2001.

18. Bryce, J. La revolución institucionalizada, Cali, Norma, 1966.

19. El Digesto de Justiniano, 3 vols., trad. de Álvaro d'Ors et al., Pamplona, Aranzadi, 1968-1975.

20. Delgado, Á. Todo tiempo pasado fue peor, Medellín, La Carreta, 2007.

21. Dewey, J. Lógica: teoría de la investigación, México DF, Fondo de Cultura Económica, 1950.

22. Engels, F. Carta a Eduard Bernstein, Londres, 3 de noviembre de 1882. Marxists Internet Archive.

23. Engels, F. "Revolución y contrarrevolución en Alemania", C. Marx y F. Engels, Obras escogidas en tres tomos, Moscú, Progreso, 1973, vol. I, pp. 307-396.

24. Engels, F. "De la autoridad”, C. Marx y F. Engels, Obras escogidas en tres tomos, vol. II, Moscú, Progreso, 1973, pp. 397-400.

25. Fariñas D., M. J. La sociología del derecho de Max Weber, México DF, UNAM, 1989.

26. France, A. El lirio rojo, Buenos Aires, Kraft, 1955.

27. Freund, J. Sociología de Max Weber, Barcelona, Península, 1967.

28. García M., G. Obra periodística, Barcelona, Mondadori, 1999.

29. Giraldo R., J. Las ideas en la guerra: justificación y crítica en la Colombia contemporánea, Bogotá, Debate, 2015.

30. Glenny, M. McMafia, el crimen sin fronteras, Barcelona, Destino, 2009.

31. Goffman, E. Internados: ensayos sobre la situación social de los enfermos mentales, Buenos Aires, Amorrortu, 1973.

32. Grupo de Memoria Histórica. ;Basta ya! Colombia: memorias de guerra y dignidad, Bogotá, Imprenta Nacional, 2013.

33. Gustafsson, B. Marxismo y revisionismo: la crítica bernsteiniana del marxismo y sus premisas histórico-ideológicas, Barcelona, Grijalbo, 1975.

34. Haley, P. "Rudolph Shom on charisma", The Journal of Religion 60, 2, 1980, pp. 185-197.

35. Hamilton, A.; J. Madison y J. Jay. El Federalista o la nueva Constitución, México DF, Fondo de Cultura Económica, 1943.

36. Hobsbawm, E. Sobre la historia, Barcelona, Crítica, 1998.

37. King, P. D. Derecho y sociedad en el reino visigodo, Madrid, Alianza, 1981.

38. Kolakowski, L. Las principales corrientes del marxismo, Madrid, Alianza, 1983.

39. Lazarsfeld, P. "Problems in methodology", R. K. Merton, L. Broom y L. S. Cottrell, Jr., eds., Sociology today: Problems and prospects, vol. I, Nueva York, Harper Torchbooks, 1965, pp. 39-78.

40. López O., J. Derecho musulmán, Barcelona, Labor, 1932.

41. Malo de M., M. Viaje á la Argelia: descripción geográfica y estadistica del Africa francesa, del desierto y de los árabes, con sus usos, costumbres, religión y literatura, Valencia, Imprenta de José Ferrer de Orga, 1852.

42. Marx, K. "Bolívar y Ponte”, K. Marx y F. Engels, Revolución en España, Barcelona, Ariel, 1960, pp. 165-184. 
43. Marx, K. y F. Engels. Correspondencia, Buenos Aires, Cartago, 1957. 44. Marx, K. y F. Engels. Manifiesto comunista, Barcelona, Crítica, 1998.

45. Marx, K. y F. Engels. Obras escogidas en tres tomos, Moscú, Progreso, 1973.

46. McLellan, D. Karl Marx: su vida y sus ideas, Barcelona, Crítica, 1977.

47. Merry, S. E. "Una clasificación de la justicia popular", El Otro Derecho 30, Bogotá, 2004, pp. 39-74.

48. Migdal, J. S. Estados débiles, Estados fuertes, México DF, Fondo de Cultura Económica, 2011.

49. Mill, J. S. Sobre la libertad, Madrid, Alianza, 1969.

50. Montanelli, I. y R. Gervaso, Historia de la Edad Media, Bogotá, Debolsillo, 2006.

51. Munné, G. "Racionalidades del derecho según Max Weber y el problema del formalismo", Isonomía 25, 2006, pp. 69-99.

52. Orwell, G. 1984, Bogotá, Debolsillo, 2016.

53. Orwell, G. Rebelión en la granja, Madrid, Millenium, 1999.

54. Rheinstein, M. "Introduction" a Max Weber on law in "Economy and Society”, Cambridge, Mass., Harvard University Press, 1954, pp. xxv-1xxi.

55. Rickert, H. Introducción a los problemas de la filosofía de la bistoria, Buenos Aires, Nova, 1961.

56. Rosental, M. y P. Iudin. Diccionario filosófico abreviado, Montevideo, Ediciones Pueblos Unidos, 1961.

57. Schapiro, L. Totalitarismo, México DF, Fondo de Cultura Económica, 1981.

58. Schmitt, C. La defensa de la Constitución, Madrid, Tecnos, 1983.

59. Semana. "Yo sobreviví a la masacre de Tacueyó", 12 de febrero de 2006.

60. Semana. "Las fosas que revivieron la masacre de Tacueyó", 27 de octubre de 2014.

61. Semana. "La estrategia para 'descontaminar' 48 municipios con minas antipersonal", 14 de septiembre de 2016.

62. Semana. 13-20 de noviembre de 2016.

63. Shakespeare, W. Medida por medida, Madrid, Aguilar, 1988.

64. Tocqueville, A. de. La democracia en América, E. Nolla, ed., Madrid, Aguilar, 1989.

65. Vargas L1., M. "El ciudadano rabioso”, El País, Madrid, 29 de octubre de 2016.

66. Weber, M. Economía y sociedad, México DF, Fondo de Cultura Económica, 2014.

67. Weber, M. Historia económica general, México DF, Fondo de Cultura Económica, 1956.

68. Weber, M. Por qué no se deben hacer juicios de valor en la sociología y en la economía, Madrid, Alianza, 2010.

69. Weber, M. ¿Qué es la burocracia?, Buenos Aires, La Pléyade, 1978.

70. Wolf, E. Rudolf von Ihering - Otto von Gierke, Madrid, Revista de Derecho Privado, s. f.

71. Zandvliet, M. Bajo la arena (Land of mine), Nordisk Film Production, 2015. 


\section{Textos jurídicos de las farc}

72. FARC-EP. Manual de convivencia para el buen funcionamiento de las comunidades, difundido por el Frente 32 del Bloque Sur de las FARC-EP el 17 de noviembre de 2013 en las montañas del Putumayo.

73. FArc-ep. Fuerzas Armadas Revolucionarias de Colombia: Ejército del Pueblo, folleto sin fecha de 110 páginas con el emblema de las FARC en la portada y el retrato de Jacobo Arenas en la contraportada. Pequeño volumen para llevar en la mochila del combatiente o para guardar en las moradas de los milicianos. Contiene:

1. Estatuto de las Fuerzas Armadas Revolucionarias de Colombia - Ejército del Pueblo, emitido por la Sexta, Séptima y Octava conferencias de las FARc, 1978, 1982 y 1993, 20 p.

2. Reglamento de Régimen Disciplinario de las Fuerzas Armadas Revolucionarias de Colombia Ejército del Pueblo, emitido por la Sexta, Séptima y Octava conferencias de las FARC, 1978, 1982 y 1993, 16 p. 3. Normas Internas de Comando de las FARC-EP, s. f., 20 p.

4. Himno de las FARC-EP, 3 p.

5. Estatutos del Partido Comunista Clandestino Colombiano (PCCC), Pleno del Estado Mayor Central de las FARC-EP, marzo de 2000, 23 p. 6. Programa Agrario de los Guerrilleros de las farc-EP, Marquetalia, 1964, 18 p.

7. Plataforma de Lucha para un Gobierno de Reconstrucción y Reconciliación Nacional, Octava Conferencia Nacional Guerrillera, 1993, 10 p. 